\title{
GESTÃO DA INFORMAÇÃO EM RECUPERAÇÃO DE ÁREAS DEGRADADAS: ANÁLISE DOCUMENTAL DO CENTRO DE REFERÊNCIA EM CONSERVAÇÃO DA NATUREZA E RECUPERAÇÃO DE ÁREAS DEGRADADAS - CRAD/UnB
}

\begin{abstract}
Monografia apresentada ao Programa de Pós-Graduação em Administração da Faculdade de Economia, Administração, Contabilidade e Ciência da Informação e Documentação (FACE), da Universidade de Brasília, como requisito parcial à obtenção do grau de Especialista em Gestão Universitária.
\end{abstract}

Orientador: Prof. Dr. José Roberto Rodrigues Pinto

Brasília - DF

2009 


\section{Agradecimentos}

Vem de ti, oh Deus, tudo o que tenho, tudo o que sou e o que vier a ser.

Agradeço a Deus por mais uma etapa conquistada em minha vida.

Minha mãe, meu pai, meus irmãos e também meus amigos, pela dedicação, pelo estímulo e pelo apoio que deram durante todos esses anos de minha vida.

Ao CRAD por disponibilizar os dados para a realização deste estudo.

Ao professor, orientador e amigo José Roberto Rodrigues Pinto, pela disponibilidade, atenção, contribuição e sábias sugestões para a realização deste trabalho.

Agradeço a todos os professores do curso que me instruíram para Especialista em Gestão Universitária. 


\section{Epígrafe}

Cada passo dado é uma possibilidade de acerto, o sucesso virá à frente, infeliz daquele que não quer dar esse passo, pois não é uma vítima do mundo, é vítima de si mesmo.

Para ser feliz corrija-se. A dor na vida de uma pessoa não muda, mas o sabor da dor depende do lugar onde a colocamos.

Viva a Vida Intensamente!

Curta, Ame, Aconteça, Conquiste, Apaixonese, Viaje, Seduza, Comemore, Queira, Sinta, Produza, Realize, Arrisque, Sonhe, Goste, Trabalhe, Estude, Brinque, Invista, Vibre, Encontre, Acredite, Abrace, Divirta-se, Viva, Enlouqueça, Invente, Busque, Sorria, Confie, Deseje, Tente, Beije, Lute, Fique, Toque, Faça, Encante, Cante, Faça poesia, Diga eu te amo, Tenha filhos, Tome banho de chuva, Diga não, Diga sim, Agradeça, Mande flores, Ponha o pé no chão e sinta a areia...

Autor: desconhecido 


\section{Sumário}

Lista de Quadros........................................................ V V

Lista de Figuras.................................................. vi

Resumo................................................................... vii

1 . INTRODUÇÃO .......................................................................................... 1

1.1 - O Problema a ser Pesquisado .................................................... 4

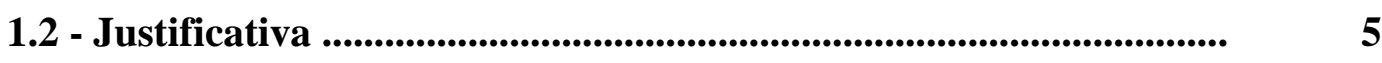

1.3 - Objetivos ................................................................................................ 7

1.3.1 - Objetivo Geral ............................................................................

1.3.2 - Objetivos Específico _................................................................... 7

2. REFERENCIAL TEÓRICO _.................................................................. 8

2.1 - Áreas Degradadas no bioma Cerrado........................................... 8

2.2 - Recuperação de Áreas Degradadas................................................ $\quad 10$

3 . METODOLOGIA .................................................................................. 11

3.1 - Tipo de Pesquisa ................................................................................... 11

3.2 - Levantamento dos Dados.............................................................. 11

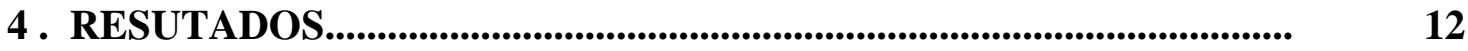

4.1 - Criação do CRAD e seus propósitos............................................... 12

4.2 - Ata de Criação do CRAD............................................................. 15

4.3 - Projetos do CRAD na Bacia do Rio São Francisco.......................... 15

4.4 - Relatório Plantios em Paracatu (MG)...................................... 18

4.5 - Outros Projetos do CRAD................................................................. 35

5 . CONCLUSÃ O........................................................................................ 41

6. CONSIDERAÇÕES FINAIS e RECOMENDAÇÕES........................... 42

7 . REFERÊNCIAS BIBLIOGRÁFICAS............................................... 44

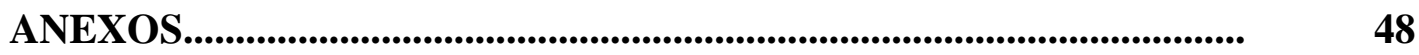




\section{LISTA DE QUADROS}

Quadro 1. Membros fundadores do CRAD e os seus respectivos locais de lotação (Faculdades / Institutos / Departamentos)

Quadro 2. Proprietários, áreas e características das propriedades levantadas e procedimentos utilizados para a recuperação e revitalização de áreas degradadas na subbacia do rio Paracatu, Bacia do São Francisco, Minas Gerais. (número de áreas e proprietários)

Quadro 3. Delineamento amostral João e Valeria 26

Quadro 4. Delineamento amostral Silvio: 5 blocos; 30 espécies e três repetições

Quadro 5. Delineamento amostral Miguel Angelo: 5 blocos; 30 espécies e três repetições

Quadro 6. Delineamento amostral Paulo Sabonja: 5 blocos; 30 espécies e três repetições 


\section{LISTA DE FIGURA}

Figura 1. Área degradada do bioma Cerrado

Figura 2. Plantio com espécies nativas do bioma Cerrado, realizado com espaçamento de $3 \mathrm{~m} \times 3 \mathrm{~m}$, para a recuperação de cascalheira da Fazenda Tangará, Paracatu, Minas Gerais

Figura 3. Plantio de sementes de Lobeira (Solanum lycocarpum) e Angicomonjolo (Acacia polyphylla) para o estabelecimento de banco de sementes na área de extração de areia Draga Três Rios, Paracatu - MG

Figura 4. Plantio de Recuperação de área degradada

Figura 5. Plantio de mudas para recuperação de área degradada na Fazenda Mão Fechada, Paracatu - MG

Figura 6. Plantio de mudas para recuperação de área alterada na Chácara São Domingo, Paracatu - MG

Figura 7. Plantio de mudas para recuperação de área alterada na Marta Neiva, Paracatu - MG

Figura 8. Plantio de mudas para recuperação de área alterada na Fazenda Sonho Meu, Paracatu - MG

Figura 9. Plantio de mudas para recuperação de área alterada na Fazenda São

Domingo, Paracatu - MG

Figura 10. Plantio de mudas para recuperação de área alterada na Fazenda Pouso Alegre, Paracatu - MG

Figura 11. Plantio de mudas para recuperação de área alterada na Fazenda Espalha, Paracatu - MG

Figura 12. Plantio de mudas para recuperação de área alterada na Cascalheira do Sabonja, Paracatu - MG

Figura 13. Plantio de mudas para recuperação de área alterada na Cascalheira da Marcia Sanders, Paracatu - MG 


\section{RESUMO}

A natureza levou milhares de anos para adquirir sua forma natural expressa na diversidade de ecossistemas e sua biodiversidade associada, que é um dos componentes mais importantes da biota. Por outro lado, as ações antrópica de alteração e degradação dos recursos naturais e falta de informações geram a preocupação com a preservação e a necessidade de trabalho de restauração ambiental. Diante deste cenário o interesse pela recuperação de áreas degradadas no Brasil encontra-se em pleno desenvolvimento. Na área acadêmica, diversos cursos em nível de mestrado e doutorado têm produzido grande número de estudos para contribuir com a evolução do tema. Historicamente até a década de sessenta a necessidade de recuperação de áreas degradadas no Brasil limitava-se quase que exclusivamente às questões de combate à erosão dos solos agrícolas e de margens de estradas e rodovias, pois se acreditava que a maioria dos biomas se encontrava em boas condições ambientais. No que diz respeito ao bioma Cerrado, a situação é mais difícil, uma vez que o Cerrado ainda hoje permanece como uma opção para os interesses relacionados à expansão da área para a produção agropecuária. A Universidade de Brasília, através do Centro de Referência e Conservação da Natureza e Recuperação de Áreas Degradadas (CRAD/UnB), criado por um grupo de professores vem atuando com projetos e parcerias na questão de recuperação de áreas degradadas, tanto recuperando áreas no bioma, como promovendo cursos com objetivo de sensibilizar os diferentes atores sociais envolvidos com a questão do uso racional dos recursos naturais renováveis. Entretanto, diante da complexidade constituída pelos conhecimentos acumulados sobre a temática a gestão da informação sobre a recuperação de áreas degradadas passa a ter uma importância transcendental para que possa ocorrer uma disseminação das informações geradas pelas pesquisas e, consequentemente, a evolução da implementação das ações recuperação das áreas degradadas. Neste sentido, este trabalho representa uma contribuição importante, uma vez que discute a gestão da informação disponibilizada pelo CRAD. A partir da análise documental pretende-se disponibilizar ao público interessado as informações de como e onde estão sendo executados os trabalhos de recuperação de áreas degradadas realizados pelo CRAD. 


\section{INTRODUÇÃO}

O interesse pela recuperação de áreas degradadas no Brasil encontra-se em pleno desenvolvimento, o que pode ser percebido pelas ações de universidades e centros de pesquisas que desenvolvem estudos científicos relacionados ao assunto, por empresas que trabalham com projetos aplicados, principalmente, de recuperação de áreas mineradas e de recuperação de processos erosivos, por organizações não governamentais e por instituições públicas.

$\mathrm{Na}$ área acadêmica, diversos cursos em nível de mestrado e doutorado têm produzido grande número de estudos para contribuir com a evolução do tema. Fauna, mineração, agricultura, pecuária, urbanização, barragens, estradas, reflorestamento e atividades industriais são temas amplos que concentraram variados estudos apresentados nos anais do VI Simpósio Nacional de Recuperação de Áreas Degradadas e Congresso Latino Americano de Recuperação de Áreas Degradadas que foi organizado pela Sociedade Brasileira de Recuperação de Áreas Degradadas (SOBRADE, 2005).

Nas universidades o assunto tem sido tratado, principalmente, pela Geologia, Agronomia, Engenharia Florestal, Biologia da Conservação, Química, Ecologia, Ecologia da Paisagem e Agroecologia. Assim como a ciência e a tecnologia, as normas legais têm acompanhado a evolução da sociedade no que diz respeito ao tema.

No Capítulo VI, sobre meio ambiente, no parágrafo primeiro e segundo, a Constituição da República Federativa do Brasil de 1988 (Brasil, 1988) determina a recuperação ambiental para situações distintas. No parágrafo primeiro, inciso I, fica exigida a necessidade de restaurar os processos ecológicos essenciais e, no parágrafo segundo, a Carta Magna obriga que "Aquele que explorar recursos minerais, fica obrigado a recuperar o meio ambiente degradado, de acordo com solução técnica exigida pelo órgão público competente, na forma da lei”.

O parágrafo primeiro, inciso I, acima referido, está regulamentado pela Lei $\mathrm{n}^{\circ} 9.985$, de 18 de julho de 2000, que institui o Sistema Nacional de Unidades de Conservação (MMA, 2000) e, em seu Artigo $2^{\circ}$, incisos XIII e XIV, define os termos recuperação e restauração.

As formas de reparação do dano ao meio ambiente são a recuperação e a compensação ecológica. A reintegração, recomposição ou recuperação do bem ambiental lesado abrange a restauração do status quo ante e também a reabilitação dos recursos 
naturais afetados. Cumpre ainda mencionar que uma vez consolidado o dano ao meio ambiente, a possibilidade de sua reparação, do ponto de vista ecológico, é remota. Tão importante quanto a recuperação do meio ambiente agredido é a cessação da atividade poluidora e a reversão da área degradada (FEPAF, 2003). No que tange à recuperação das áreas atingidas pelo dano ecológico, o artigo 225, §2 da Constituição Federal, alude que: "Aquele que explorar recursos minerais fica obrigado a recuperar o meio ambiente degradado, de acordo com solução técnica exigida pelo órgão público competente, na forma da lei."

Da mesma forma, a Lei $\mathrm{n}^{\circ}$ 6.938, de 31 de agosto de 1981, que dispõe sobre a Política Nacional do Meio Ambiente (http://www.presidencia.gov.br/legislacao/), em seu artigo $2^{\circ}$ está descrito que a política nacional do meio ambiente tem por objetivo a preservação, melhoria e recuperação da qualidade ambiental propícia à vida, visando assegurar, no país, condições ao desenvolvimento socioeconômico, aos interesses da segurança nacional e à proteção da dignidade da vida humana. Agora, nos casos em que a restauração ecológica é inadequada ou inviável, a legislação ambiental prevê a compensação ecológica.

A Lei $\mathrm{n}^{\circ}$ 9.605, de 12 de fevereiro de 1998, Lei dos Crimes Ambientais, e o Decreto $n^{\circ} 3.179$ (MMA, 2006), que dispõe sobre a especificação das sanções aplicáveis às condutas e atividades lesivas ao meio ambiente, também garantem a recuperação da degradação ambiental. No artigo segundo, parágrafo único, da Lei $\mathrm{N}^{\circ}$ 10.259/01, diz "consideram-se infrações de menor potencial ofensivo para os efeitos desta Lei, os crimes a que a Lei comine pena próxima não superior a dois anos, ou multa". Como se observa, o Brasil conta com importantes instrumentos legais, técnicos e científicos para que a recuperação de áreas degradadas seja implementada.

Dentre as condutas ofensivas ao meio ambiente estão os crimes contra a fauna (art. 29), contra a flora (art. 38 e 40, principalmente), contra a administração pública do patrimônio público ambiental (66,67 e 68), os crimes de poluição (art. 54) e os crimes contra o ordenamento urbano e o patrimônio cultural (art. 62 a 65). Reza o art. 64, por exemplo, que é crime "promover em solo não edificável, ou no seu entorno, assim considerado em razão de seu valor PAÍSAGISTICO, ECOLÓGICO, ARTÍCO, TURÍSTICO, HISTÓRICO, CULTURAL, RELIGIOSO, ARQUEOLÓGICO ETINOGRÁFICO OU MONUMENTAL, sem autorização da autoridade competente ou em desacordo com a concedida: Pena - Detenção de 6 meses a 1 ano e multa”. ( Felfili \& Santos, 2002: p.58). 
Até a década de sessenta a necessidade de recuperação de áreas degradadas no Brasil limitava-se quase que exclusivamente às questões de combate à erosão dos solos agrícolas e de margens de estradas e rodovias, uma vez que a maioria dos biomas encontrava-se ainda em boas condições ambientais (CORREA, 1959). A partir daí, com a adoção das medidas impostas pela revolução verde, a crescente mecanização da agricultura, a expansão da industrialização e a ampliação das cidades, o processo de fragmentação dos biomas passou a exercer uma pressão importante sobre a conservação e preservação das espécies e sobre os serviços ambientais (MMA, 2003; ARAÚJO \& SOUZA, 2003).

No que diz respeito ao Cerrado, a situação é ainda mais difícil, uma vez que este passou a ser considerado como celeiro do mundo e sequer foi considerado pela Constituição de 1988 como patrimônio nacional, conforme estabelece o $\S 4^{\circ}$ do capítulo de meio ambiente: "A Floresta Amazônica brasileira, a Mata Atlântica, a Serra do Mar, o Pantanal Mato-Grossense e a Zona Costeira são patrimônio nacional, e sua utilização farse-á, na forma da lei, dentro de condições que assegurem a preservação do meio ambiente, inclusive quanto ao uso dos recursos naturais".

O Cerrado hoje permanece uma opção para todos os interesses relacionados à expansão da área para a produção agropecuária. A política agrícola continua com a mesma visão de meados da década de sessenta, quando desbravar as áreas de cerrado e aplicar grandes doses de agrotóxicos e adubos sintéticos era considerado "recuperação do cerrado" (MMA, 1964). Vários autores têm alertado para situação precária e preocupante de conservação do bioma Cerrado (KLINK, 2005).

Diante da complexidade constituída pelos conhecimentos acumulados sobre a temática na área legal, científica, técnica, econômica, ambiental e social, a gestão da informação sobre a recuperação de áreas degradadas passa a ter uma importância transcendental para que possa ocorrer uma evolução mais rápida da recuperação das áreas degradadas.

Neste sentido, este trabalho representa uma contribuição importante, uma vez que discute a gestão da informação disponibilizada pelo Centro de Referência em Conservação da Natureza e Recuperação de Áreas Degradadas - CRAD. No universo de recuperação de áreas degradadas, segundo Amaral (1996), "Informação como recurso para o desenvolvimento sócio-econômico mostra a importância das unidades de informação, como organizações essenciais, com efetiva participação para promover o desenvolvimento da sociedade". 
A Lei $\mathrm{n}^{\circ}$ 4.771, de 15/09/65, posteriormente modificada pelas Leis $n^{\circ} 7.754,7.803$ e $\mathrm{n}^{\circ} 7.875$, instituiu o Código Florestal Brasileiro. Dentre as modificações estão a inclusão de outras áreas como sendo de Preservação Permanente como as: APPs, que são as Áreas de Preservação Permanente que são áreas protegidas nos termos dos arts. $2^{\circ}$ e $3^{\circ}$ desta Lei, coberta ou não por vegetação nativa, com função ambiental de preservar os recursos hídricos, a paisagem, a estabilidade geológica, a biodiversidade, o fluxo gênico da fauna e flora, proteger o solo e assegurar o bem-estar das populações humanas e a RL que é a Reserva Legal sendo parte de uma área localizada no interior de uma propriedade ou posse rural, excetuada a de preservação permanente, necessária ao uso sustentável dos recursos naturais, à conservação e reabilitação dos processos ecológicos, à conservação da biodiversidade e ao abrigo e proteção de fauna e flora nativa. (Felfili \& Santos, 2002 : 27-28). 


\section{1 - O problema a ser pesquisado}

Segundo Ribeiro \& Walter (2008), o bioma Cerrado ocupa cerca de 23\% do território brasileiro e está localizado na porção central do Brasil, ocorrendo na região Centro-Oeste e parte das regiões Sudeste, Norte e Nordeste. A preservação da vegetação nativa deste bioma requer extrema atenção para conter ou pelo menos minimizar a degradação ambiental que vem sendo imposta pelos setores agropecuário, agropastoril e outros que vem somando à cota de destruição do Cerrado, como no caso do turismo sem planejamento (Figura 1). Nesse cenário surgem algumas indagações que ainda carecem de respostas, ou ao menos, algum tipo de investigação, por exemplo, como efetuar os plantios de recuperação de áreas degradadas e que espécies usar em cada tipo de plantios (Felfili et al., 2002).

Com esta pesquisa pretende-se disponibilizar resultados das mais novas pesquisas na área de recuperação de áreas degradadas feitas por um Centro Especializado (Centro de Referência em Conservação da Natureza e Recuperação de Áreas Degradadas - CRAD).

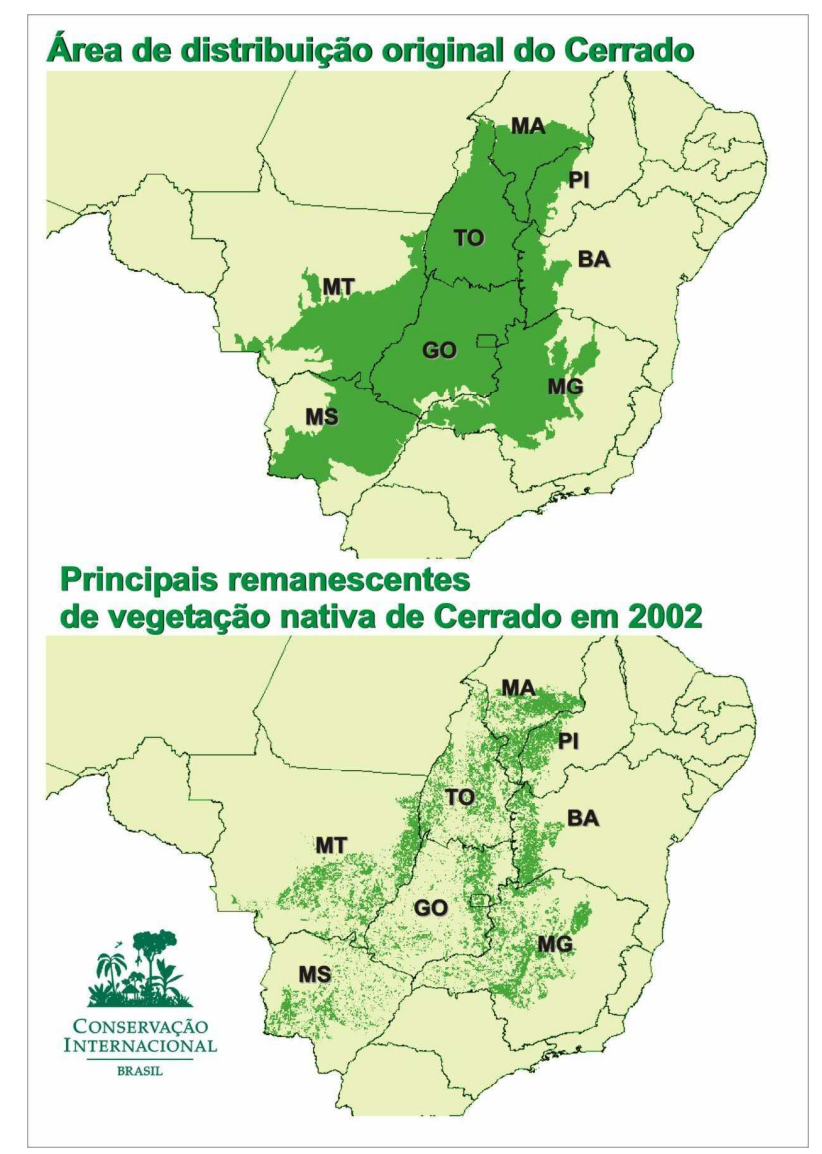

Figura 1. O avanço da área degradada do bioma Cerrado.

Fonte: www.ispn.org.br, acessado em 19/04/2009. 


\section{2 - Justificativa}

É desejável que a proposta de recuperação de áreas degradadas no Cerrado venha contribuir no processo de mudança de comportamento das pessoas que por motivos econômicos e financeiros degradam a natureza que perpassou milhares de anos para obter a sua forma.

Assim, o presente estudo visa contribuir para disponibilizar, em diversos níveis, a disseminação de informações e fomentar iniciativas de sensibilização social que resultem nas ações feitas pelo CRAD/UnB.

Para uma educação ambiental aplicada é de suma importância a participação da comunidade local, envolvendo proprietários rurais, técnicos, instituições governamentais e não-governamentais para discussões que norteiam as ações de implementação dos projetos de recuperações de áreas degradadas (Felfili et al., 2002).

Com a gestão de informação sobre as ações de recuperação de áreas degradadas no bioma Cerrado, espera-se abrir portas para esclarecimentos sobre as atividades (irregulares) que o trabalhador rural faz no seu dia-a-dia. Estas informações são oriundas de encontros e trabalhos executados com as devidas orientações técnicas apropriadas de práticas modernas de recuperação e conservação da natureza. Por exemplo, um dos produtos já gerado pelo CRAD/UnB foi a publicação do livro "Conservação da Natureza e recuperação de Áreas Degradadas na Bacia do São Francisco: treinamento e sensibilização" (Felfili et al., 2008). Neste livro foram abordados assuntos referentes a informações técnicas sobre recuperação de áreas degradadas do Cerrado, bem como técnicas de motivação e sensibilização de multiplicadores desses conhecimentos.

Outra ação importante executada pelo CRAD/UnB foi o treinamento realizado com escolas, produtores rurais e outros movimentos sociais em parceria com o Instituto Estadual de Florestas nas cidades de Paracatu-MG, com mais de 80 participantes e Januária-MG, com mais de 120 participantes. (Felfili et al., 2008).

Por outro lado, as ações antrópica de alteração e degradação do Cerrado e falta de informações, gera a preocupação com a preservação e a necessidade de trabalho de restauração da flora, que não é de pouco tempo, os quais vêm sendo tratados em seminários, debates vocacionais em todos os meios, inclusive entre os cientistas. A exemplo disso, no ano de 2008, a Embrapa Cerrados realizou em Brasília, no mês de outubro, o IX Simpósio Nacional sobre o Cerrado e o II Simpósio Internacional de Savanas 
Tropicais. Entre os temas tratados no evento estava a questão da recuperação de áreas degradadas do bioma Cerrado, além de discutir temas relacionados aos avanços e novas perspectivas das pesquisas no Cerrado, visando ao equilíbrio entre sociedade, agronegócio e recursos naturais (Embrapa, 2003).

Segundo Felfili et al. (2002) há uma crescente busca de informações sobre projetos de recuperação de áreas degradadas com técnicas apropriadas. Contudo, ainda são insuficientes, principalmente pelas quantidades e diferentes fontes de degradação ocorrentes detectadas, tipo de vegetação e condições ambientais que foram sujeitas a degradação (Felfili et al., 2002).

Autores escrevem, sobre áreas degradadas e alterações de ecossistema natural, como por exemplo, no Distrito Federal, para cada hectare urbanizado, outro é alterado pelos impactos diretos e indiretos das atividades humanas (CORREA, 1998).

A presença do homem sem um comportamento adequado nos aponta sinais de dúvidas sobre a intervenção no ecossistema. Correa (1998) cita que caso o ambiente não se recupere sozinho, diz-se que o ambiente está degradado e necessita da intervenção humana. Segundo este mesmo autor se o ambiente mantém a capacidade de regeneração ou depuração, diz-se que o ambiente está perturbado e a intervenção humana apenas acelera o processo de recuperação (CORREA, 1998).

Com a gestão de informação sobre as ações de recuperação de áreas degradadas no bioma Cerrado, abrir-se portas para esclarecimentos sobre essa complexa atividade (irregular) que o trabalhador rural faz no seu dia-a-dia, onde através de encontros e trabalhos executados com as devidas orientações técnicas apropriadas de práticas modernas em recuperação e conservação da natureza.

O desejo maior com essa investigação é certamente o de analisar informação das que o CRAD/UnB dispõe em seu acervo, no sentido de divulgar as ações que foram e que serão realizadas a partir de idéias que tenham sido aplicadas nas áreas degradadas do bioma Cerrado. A melhoria do cenário biológico do Cerrado virá com medidas plausíveis de querer o natural original dentro da especificidade harmônica de convivência do homem, animais e árvores, conservando o mais importante, a vida para o futuro. 


\section{3 - Objetivos}

\subsection{1 - Objetivo Geral}

Analisar as informações geradas a partir das ações do Centro de Referência em Conservação da Natureza e Recuperação de Áreas Degradadas - CRAD/UnB, na temática recuperação das áreas degradadas no bioma Cerrado. A partir desta análise documental pretende-se disponibilizar ao público interessado as informações de como e onde estão sendo executados os trabalhos de recuperação de áreas degradadas realizados pelo CRAD/UnB.

\subsection{2 - Objetivos Específicos}

- Apresentar a idealização da criação e propósito do Centro de Referência em Conservação da Natureza e Recuperação de Áreas Degradadas - CRAD/UnB.

- Localizar as áreas degradadas com ações de recuperação por parte do CRAD/UnB, em suas respectivas regiões e descrever o tipo de degradação que ocorreram nas áreas.

- Citar os tipos de recuperação e aplicabilidade das técnicas adotadas pelo CRAD/UnB no processo de recuperação das áreas degradadas em função da diversidade dos locais escolhidos para implementação das ações de recuperação.

- Disponibilizar ao público em geral, em todos os níveis as ações de recuperação de áreas degradadas do bioma Cerrado desenvolvido pelo CRAD/UnB. 


\section{REFERENCIAL TEÓRICO}

\section{1 - Áreas degradadas no Cerrado}

O patrimônio natural brasileiro expresso pela extensão continental, pela diversidade e endemismo das espécies biológicas e seu patrimônio genético, bem como pela variedade ecossistêmica dos biomas, apresenta grande relevância mundial (ASSUNÇÃO \& FELFILI, 2004). Por este lado a crescente exploração dos recursos naturais tem levado a perdas de muitas espécies sem antes tê-las estudado ou mesmo tomado conhecimento de suas existências (CALDATO et al., 1996).

Os ecossistemas tropicais em todo o mundo continuam ameaçados pela degradação descontrolada e pela conversão para outros tipos de uso da terra, sob a influência da crescente demanda por produtos florestais, da expansão agrícola e do mau manejo dos recursos naturais existentes. Os impactos da perda da biodiversidade pela degradação ambiental aparecem sob a forma de erosão do solo, dano aos habitats silvestres e degradação das áreas de bacias, deterioração da qualidade da vida e redução das opções de usos dos recursos para a promoção do desenvolvimento local (SIMINSKI et al., 2004).

Essas alterações do uso da terra podem representar ameaças à biodiversidade (genética, de espécies e de ecossistemas) no Cerrado (ANDRADE et al., 2002).

Apesar da crescente conscientização sobre a importância biológica dos ecossistemas naturais, como abrigo para a fauna, corredores de passagem para espécies silvestres e filtro natural dos cursos d'água, pouco se sabe sobre as interações entre as comunidades vegetais e os fatores abióticos que sustentam estas fitofisionomias (MORENO \& SCHIAVINI, 2001). Deste modo, estudos em áreas silvestres não alteradas são essenciais para que se tenha compreensão dessas complexas estruturas, dando maior ênfase a investigações com enfoque no comportamento ecológico dos seres no ecossistema (CALDATO et al., 1996). Assim, os estudos de comunidades vegetais afetadas pelo desenvolvimento das atividades humanas relacionadas à urbanização são importantes instrumentos para a manutenção desses frágeis ecossistemas (SALLES \& SCHIAVINI, 2007).

A ênfase no cerrado surge de repente pela sua importância e por ser o segundo maior bioma nacional e uma das áreas de maior diversidade no mundo, constituída por um mosaico vegetacional composto por formações campestres (campos limpo, sujo e rupestre), 
savânicas (cerrado sensu stricto, cerrado denso, cerrado ralo e cerrado rupestre) e florestais (cerradão, matas de galeria, ciliares e secas) (MORENO \& CARDOSO, 2005).

No Brasil, a composição florística de comunidades vegetais ainda é desconhecida em extensões consideráveis de seu território florestado. Entretanto, estudos dessa natureza em florestas tropicais têm sido intensificados nas últimas décadas, não apenas com relação à descrição da sua composição florística e estrutura fitossociológica, mas também buscando entender a dinâmica desses ecossistemas (LONGHI et al., 2006). Por esse motivo explicitado nos conduz a real necessidade e importância para subsidiar as ações de recuperação das áreas degradadas. 


\section{2 - Recuperação de áreas degradadas}

A recomposição florística de um ecossistema natural é de grande importância para proteger o solo e estabelecer condições para a sucessão vegetal, visando atingir uma comunidade mais estável (ÂNGELO et al., 2002), e conservar a biodiversidade. São utilizados modelos de sucessão para revegetação das áreas degradadas, que buscam imitar a sucessão que ocorre naturalmente, recuperando a forma original do ecossistema e também de suas funções. Para tal é importante priorizar a utilização de espécies nativas, objetivando a conservação da biodiversidade e diminuindo o risco de perdas por dificuldade de aclimatação (Felfili et al.,2002). No entanto, a falta de conhecimento sobre as plantas nativas pode dificultar os programas de recuperação (OLIVEIRA-FILHO, 1994).

No processo de recomposição do ecossistema podem ser utilizadas duas técnicas diferentes (dependendo das condições locais e dos recursos financeiros disponíveis). As técnicas são: a restauração e a revegetação. Sendo esta última dividida em recuperação e reabilitação. Segundo Franco et al. (1992), a restauração é feita quando o ecossistema mantém seus meios de regeneração biótica, podendo ou não receber ajuda do homem introduzindo mudas de espécies nativas. A revegetação é utilizada em ambientes degradados desprovidos de meios naturais de regeneração, sendo que na recuperação são empregadas espécies pré-existentes, e na reabilitação, as espécies utilizadas são exóticas ou de outros ecossistemas locais (Franco et al., 1992).

"A reabilitação de um ambiente degradado ou perturbado consiste na restauração das suas características originais a partir de plantios mistos de espécies nativas já adaptadas às condições naturais do ambiente e que possam vir a criar condições de solo e de microclima similar às encontradas antes da ação de degradação. Estas espécies devem gerar abrigo e recursos, tais como frutos, pólen e outros produtos de modo que a flora e fauna silvestre associadas possam recolonizar a área" (Felfili et al., 2008). 


\section{METODOLOGIA}

\section{1 - Tipo de pesquisa}

A pesquisa é descritiva a partir de análise documental, a qual buscará descrever com o máximo de fidelidade o apanhado de informações no arquivo do Centro de Referência em Conservação da Natureza e Recuperação de Áreas Degradadas - CRAD/UnB.

Segundo Amaral (2003), "é fato incontestável que mudanças e transformações ocorrem na sociedade. É certo também que os avanços das tecnologias de informação e comunicação afetam o comportamento dos indivíduos."

A fundamentação da pesquisa foi de buscas constantes, no acervo dos dados do CRAD/UnB, de normas e procedimentos proferidos para sustentabilidade da intenção a ser registrada nos anais deste trabalho com formulações de novos dados informativos de fácil entendimento e numa linguagem de fácil assimilação.

Foi feito também visitação in loco nas propriedades onde foram implantados modelos de recuperação no município de Paracatu-MG, para melhor entendimento e assimilação da filosofia agregada ao serviço no que se refere aos atores envolvidos em todo o processo e da materialização dos meios.

\section{2 - Levantamento dos dados}

Foram consultadas as seguintes fontes de dados:

A. Arquivos do acervo e banco de dados do CRAD/UnB para a obtenção do material a ser coletado, vistoriado e organizado sobre critérios adotado, levando em conta a proposta de criação do Centro Especializado, mostrando a capacidade de mobilização de um grupo de professores da UnB em prol da expectativa e adesão que o grupo mantém pela causa do bioma Cerrado, mais especificamente sobre a recuperação de suas áreas degradadas.

B. Investigação in loco das áreas que estão em processo de recuperação e as que serão recuperadas, como ações do $\mathrm{CRAD} / \mathrm{UnB}$, mostrando sua situação através de documentos fotográficos e relatórios das atividades de recuperação das áreas degradadas, bem como as características bióticas e abióticas das áreas, suas peculiaridades em resposta ao trabalho executado e os modelos de recuperação que foram desenvolvidos nas áreas. 


\section{RESULTADOS E DISCUSSÃO}

\section{1 - Criação do CRAD e seus propósitos}

O Centro de Referência em Conservação da Natureza e Recuperação de Áreas Degradadas (CRAD/UnB) foi criado em 5 de outubro de 2007 pelo reitor da Universidade de Brasília (UnB) no uso de suas obrigações, sob a Resolução do Conselho Universitário no 32/2007 (Anexo 1). O Centro foi criado como um pólo gerador e difusor de conhecimentos e que possibilitará a integração de grupos de pesquisa já consolidados a atuarem numa abordagem transversal de temas de grande interesse para a humanidade. Os principais objetivos do CRAD/UnB estão pautados na geração de conhecimentos e desenvolvimento de modelos de recuperação de áreas degradadas em diferentes condições de campo, tanto do ponto de vista fitogeográfico, fitofisionômico e socioambiental. O CRAD/UnB tem como missão propor soluções com base na pesquisa científica multidisciplinar relativa aos temas Conservação da Natureza e Recuperação de Áreas Degradadas, além de capacitar os atores sociais em diversos níveis e na extensão no que se refere à disseminação de informações, sensibilização de interessados quanto aos temas correlatos e articulação institucional.

As atividades do $\mathrm{CRAD} / \mathrm{UnB}$ apresentarão um caráter inovador e complementar àquelas já desenvolvidas nos Departamentos e Unidades Acadêmicas existentes na UnB, tendo como diferencial a transversalidade dos temas abordados e o caráter de articulação institucional, onde se pretende congregar por meio de parcerias com instituições, organizações governamentais e não-governamentais, para o desenvolvimento de ações conjuntas que levem a soluções inovadoras, com abordagem efetiva e de pronta aplicação, visando o manejo e a recuperação de áreas degradadas.

Já é política governamental, por meio dos Ministérios de Ciência e Tecnologia MCT e do Ministério do Meio Ambiente - MMA, dentre outros, o estímulo à criação de redes integrando grupos e instituições de pesquisa para resolver temas complexos de interesse nacional, tema objeto de vários editais publicados pelo governo brasileiro. Em sintonia com este modelo, os proponentes do CRAD/UnB participam de grupos de pesquisa que têm atuado na formação de redes, como a Rede de Sementes do Cerrado, a Rede de Parcelas Permanentes dos Biomas Cerrado e Pantanal, e em projetos multidisplinares, especialmente dos Programas Programa de Apoio a Núcleos de 
Excelência e Pesquisas Ecológicas de Longa Duração - PELD, além de projetos de cooperação internacional com o Reino Unido e outros países. A percepção, diante do contexto atual, é a de que se faz necessária a integração dos diferentes grupos de pesquisa que tratam dos processos ecológicos, da diversidade biológica, dos recursos hídricos e do meio físico para o alcance de propostas sustentáveis do ponto de vista da conservação e da restauração da biodiversidade, recursos hídricos e processos ecológicos. Faz-se necessária, também, a capacitação em diversos níveis, profissionais, técnicos e produtores rurais por meio de instrumental técnico com abordagem integrada, baseada em modelos inovadores permeados pela temática da sustentabilidade, da biodiversidade e da restauração das funções ecológicas dos ecossistemas e áreas degradadas.

A Universidade de Brasília, com a criação deste Centro Especializado, consolidará assim a sua posição de vanguarda no desenvolvimento científico e tecnológico, visando a temática da Conservação da Natureza e a Recuperação de Áreas Degradadas com a integração dos grupos de pesquisa que ora atuam nos meios bióticos e abióticos que compõem os ecossistemas a serem recuperados, assim como na dimensão socioeconômica e socioambiental e na formação de redes de informação relacionadas a temática conservação da natureza e recuperação de áreas degradadas.

A criação do $\mathrm{CRAD} / \mathrm{UnB}$ vem consolidar uma série de iniciativas desenvolvidas pelos proponentes e seus respectivos grupos de pesquisa ao longo de décadas de atuação na questão ambiental, todos credenciados na instituição e validados pelo Conselho Nacional de Desenvolvimento Científico e Tecnológico - CNPq. O ponto focal refere-se à demanda dos Ministérios do Meio Ambiente e do Ministério da Integração Regional, representado pela Companhia de Desenvolvimento do Vale do São Francisco e Parnaíba - CODEVASF para que a Universidade de Brasília integre o Programa de Revitalização da Bacia do São Francisco - PRSF, no âmbito da criação de Centros de Referência para Recuperação de Áreas Degradadas - CRad. A UnB em dezembro de 2006 assumiu o compromisso junto a CODESVASF de implementar o Centro de Referência em Recuperação de Áreas Degradadas na bacia do Médio São Francisco, bioma Cerrado.

Na ocasião o convênio firmado entre a CODEVASF e a Fundação Universidade de Brasília - FUB disponibilizou para a UnB recursos na ordem de $\mathrm{R} \$ 750.000,00$, para aquisição de equipamentos, visando o monitoramento dos processos de restauração do ponto de vista do meio biótico e abiótico, assim como recursos para a edificação de instalações físicas no campus da UnB destinada para laboratórios, para área administrativa e gerenciamento do programa e espaço para capacitação e treinamento. A implantação do 
CRAD/UnB prevê ainda o estabelecimento de parceria da UnB como o Instituto Estadual de Florestas de Minas Gerais (IEF) para a utilização de um Centro de Treinamento e Educação Ambiental, em Paracatu-MG.

$\mathrm{Na}$ linha de geração e repartição de benefícios advindos da recuperação, integrantes da equipe proponente deste Centro conceberam e vem desenvolvendo em parceria com órgãos governamentais, como Empresa Brasileira de pesquisa Agropecuária - EMBRAPACERRADOS, Instituto Nacional de Colonização e Reforma Agrária - INCRA e MMA e organizações não-governamentais, como a Rede de Sementes do Cerrado e o Instituto Vida Verde o Projeto MDR - Módulos Demonstrativos de Recuperação de Áreas Degradadas de Cerrado com Espécies Nativas do Bioma de Uso Múltiplo onde a recuperação se faz com espécies nativas que gerem renda ao produtor rural e incentivando-o proteger os remanescentes de vegetação nativa e a recuperar as áreas degradadas. A mais recente demanda vem do MMA por meio do Programa das Nações Unidas para o Desenvolvimento - PNUD para a implantação de modelo de treinamento teórico e prático e capacitação dos agricultores da bacia do São Francisco em conservação, recuperação e manejo sustentável dos recursos naturais, que culminou com a publicação do livro Conservação da Natureza e Recuperação de Áreas Degradadas na Bacia do São Francisco Treinamento e Sensibilização.

Em função da crescente demanda e da necessidade de soluções multidisciplinares para a temática, os proponentes elaboraram esta proposta para a criação do Centro de Referência em Conservação da Natureza e Recuperação de Áreas Degradadas, com vistas a realizar pesquisas multidisciplinares, voltadas à geração de conhecimento e desenvolvimento de modelos relacionados ao uso sustentável dos recursos naturais; ensino em diversos níveis, com vistas a capacitar pessoal para atuar na área de conservação da natureza e recuperação de áreas degradadas e extensão, especialmente em relação à sistematização e disseminação de conhecimentos, sensibilização para a temática ambiental, mobilização e articulação institucional. 


\section{2 - Ata de criação do CRAD}

Foi realizada no dia 25 de outubro de 2007 à primeira reunião para a criação do Centro Especializado em Centro de Conservação da Natureza e Recuperação de Áreas Degradadas - CRAD/UnB, instalação do Conselho e eleição da Diretoria deste Centro Especializado, conforme a ata (Anexo 1). E conta com pesquisadores de diversas áreas de conhecimento (quadro 1).

O Centro Especializado em Conservação da Natureza e Recuperação de Áreas Degradadas - CRAD/UnB, como é um Centro Especializado da Universidade de Brasília e para a sua gestão tem definição, disposições e ações que devem ser regidas mediante ao Regimento Interno (Anexo 2) e a Resolução do Conselho Universitário No 32/2007 (Anexo 4).

Quaro 1. Membros fundadores do CRAD e os seus respectivos locais de lotação.

\begin{tabular}{|l|l|l|}
\hline \multicolumn{1}{|c|}{ NOME } & LOTAÇÃO & \multicolumn{1}{c|}{ FUNÇÃO } \\
\hline Jeanine Maria Felfili & FT/EFL & Diretora Presidente \\
\hline José Roberto Rodrigues Pinto & FT/EFL & Diret.Vice-Presidente \\
\hline Carmen Regina Mendes de Araújo Correia & FT/EFL & Diretora Administrativa \\
\hline Augusto César franco & DB/IB & Membro fundador \\
\hline Chistopher William Fagg & FT/EFL & Membro fundador \\
\hline John Du Vall Hay & DE/IB & Membro fundador \\
\hline Manoel Cláudio da Silva Júnior & FT/EFL & Membro fundador \\
\hline Mercedes Maria da cunha Bustamante & DE/IB & Membro fundador \\
\hline Mundayatan Haridasan & DE/IB & Membro fundador \\
\hline Nabil Josph Eid & FT/DEC & Membro fundador \\
\hline Reuber Albuquerque Brandão & FT/EFL & Membro fundador \\
\hline Humberto Abdala Júnior & FT/DEE & Membro fundador \\
\hline José Camapum de Carvalho & FT/DEC & Membro fundador \\
\hline Laís Maria Borges de Mourão Sá & FE/CDS & Membro fundador \\
\hline Leila Chalub & FE/DTF & Membro fundador \\
\hline Newton Moreira de Sousa & FT/DEC & Membro fundador \\
\hline Sérgio Koide & FT/DEC & Membro fundador \\
\hline Evandro Luiz Mendonça Machado & UFVJM & Membro Pesquisador \\
\hline
\end{tabular}




\section{3 - Projetos do CRAD na Bacia do Rio São Francisco}

Foram implantados os modelos de recuperação adotados pelo Centro de Conservação da Natureza e Recuperação de Áreas Degradadas - CRAD/UnB em 12 áreas no Município de Paracatu onde se encontra um dos maiores afluentes do Rio São Francisco, o Rio Paracatu. Nessas áreas as ações de subtrações levaram a degradação do solo, numa primeira foi explorada com extração de areia, numa segunda foram quatro áreas de extração de cascalho e na terceira foram sete áreas maiores destinadas a uso de pastagens. Dando um total de 25 ha de área já em processo de recuperação, com tratamento de 23.799 mudas de espécies plantas nativas e 92 espécies de plantas diferentes (Anexo 3). Veja a quantificação expostas nas amostras seguintes (Quadro 2 e as Figuras 2 a 13). 
Quadro 2. Informações das doze áreas com ações de recuperação na sub-bacia do rio Paracatu, Bacia do São Francisco, em Paracatu, MG. Proprietários, áreas e características das propriedades levantadas e procedimentos utilizados para a recuperação e revitalização de áreas degradadas.

\begin{tabular}{|c|c|c|c|c|c|c|c|}
\hline Área & Proprietário & $\begin{array}{l}\text { Propriedade } \\
\text { Contato }\end{array}$ & $\begin{array}{l}\text { Área } \\
\text { (ha) }\end{array}$ & Localização & Procedimentos & Previsão & Rio / Bacia \\
\hline 1 & Alcino Xavier Borges & $\begin{array}{l}\text { Fazenda Tangará } \\
\text { (cascalheira) / (38) } \\
9962-3265\end{array}$ & 2,5 & $\begin{array}{l}\text { UTM: } 80.973 .13 \mathrm{~S} / \\
\text { 02.953.46 E - } \\
\text { Lat/Long: } 17^{\circ} 11^{\prime} 59^{\prime \prime} \\
\text { S / } 46^{\circ} 55^{\prime} 27^{\prime \prime} \mathrm{W}\end{array}$ & $\begin{array}{l}\text { Plantio realizado em fevereiro de } \\
2008 \text {, sob a supervisão do Sr. } \\
\text { Neivaldo, totalizando } 2329 \text { mudas } \\
\text { de } 42 \text { espécies. Medição das } \\
\text { plantas no tempo zero realizado } \\
\text { em maio de } 2008 \text {. Experimento } \\
\text { com cobertura morta e adubo } \\
\text { orgânico implantado em julho de } \\
2008 \text {. }\end{array}$ & $\begin{array}{l}\text { Julho/2008, aplicação de } \\
\text { cobertura morta e } \\
\text { adubação orgânica; } 2^{\circ} \\
\text { sem.: monitoramento das } \\
\text { plantas. }\end{array}$ & $\begin{array}{l}\text { Córrego do Espalha } \\
\text { / Micro bacia do } \\
\text { Espalha/ Bacia do } \\
\text { Paracatu. }\end{array}$ \\
\hline 2 & Alcino Xavier Borges & $\begin{array}{l}\text { Draga Três Rios / } \\
\text { (38) 9962-3265 }\end{array}$ & 3,0 & $\begin{array}{l}\text { UTM: } 80.621 .44 \mathrm{~S} / \\
\text { 03.377.36 E - } \\
\text { Lat/Long: } 17^{\circ} 31^{\prime} 42^{\prime \prime} \\
\text { S / } 46^{\circ} 31^{\prime} 42^{\prime \prime} \mathrm{W}\end{array}$ & $\begin{array}{l}\text { Plantio do experimento do banco } \\
\text { de sementes resistentes e } \\
\text { recolocação da camada fértil do } \\
\text { solo com retroescavadeira, } \\
\text { realizados em } 2 \text { e } 3 \text { de maio de } \\
2008 \text {. }\end{array}$ & $\begin{array}{l}\text { junho: instalação de } \\
\text { poleiros } \\
\text { enriquecimento do banco } \\
\text { de sementes ; avaliação } \\
\text { da germinação e } \\
\text { sobrevivência do banco } \\
\text { de sementes / Outros } \\
\text { procedimentos. }\end{array}$ & $\begin{array}{l}\text { Rio do Prata / } \\
\text { Bacia do Paracatu. }\end{array}$ \\
\hline 3 & $\begin{array}{l}\text { João e Valéria Pimentel } \\
\text { Barbosa Lucas }\end{array}$ & $\begin{array}{l}\text { Fazenda } \\
\text { Antônio dos Olhos } \\
\text { d'água (Fecha Mão); } \\
(38) \text { 9974-4574 / } \\
8821-1454 \text { / } 3671- \\
1454 \text { / } 3671-1784\end{array}$ & 1,0 & $\begin{array}{l}\text { UTM } 8071008 \mathrm{~S} \mathrm{/} \\
319420 \mathrm{E}- \\
\text { Lat/Long: } 17^{\circ} 26^{\prime} 21^{\prime \prime} \\
\text { S / 46 } 42^{\prime} 00^{\prime \prime} \mathrm{W}\end{array}$ & $\begin{array}{l}\text { Plantio de } 744 \text { mudas de } 30 \\
\text { espécies, em março de } 2008 . \\
\text { Medição das plantas no tempo. } \\
\text { zero realizado em maio de } 2008 .\end{array}$ & $\begin{array}{l}2^{\circ} \text { sem.: monitoramento } \\
\text { das plantas. }\end{array}$ & $\begin{array}{l}\text { Córrego Fecha Mão } \\
\text { / sub-bacia do } \\
\text { Escuro / Bacia do } \\
\text { Paracatu. }\end{array}$ \\
\hline 4 & Márcia Sanders & $\begin{array}{l}\text { Fazenda } \\
\text { Horizonte } \\
36712266\end{array}$ & 4,5 & $\begin{array}{l}\text { UTM: } 80.53 .418 \mathrm{~S} / \\
\text { 03.02.637 E - } \\
\text { Lat/Long: } 17^{\circ} 35^{\prime} 48^{\prime \prime} \\
\text { S / } 46^{\circ} 51^{\prime} 35^{\prime \prime} \mathrm{W}\end{array}$ & $\begin{array}{l}\text { Plantio de } 1503 \text { mudas de } 39 \\
\text { espécies, em fevereiro de } 2008 . \\
\text { Medição das plantas no tempo. } \\
\text { zero realizado em junho de } 2008 \text {. }\end{array}$ & $\begin{array}{l}\text { Julho: estabelecimento } \\
\text { do experimento para } \\
\text { controle de gramíneas } \\
\text { invasoras; } 2^{\circ} \text { sem.: } \\
\text { monitoramento } \\
\text { plantas. }\end{array}$ & $\begin{array}{l}\text { Córrego do Ouro / } \\
\text { Bacia do Paracatu. }\end{array}$ \\
\hline
\end{tabular}




\begin{tabular}{|c|c|c|c|c|c|c|c|}
\hline 5 & Márcia Sanders & $\begin{array}{l}\text { Cascalheira Sanders } \\
\text { / (38) } 36712266\end{array}$ & 3,0 & $\begin{array}{l}\text { UTM 80.95.098 S / } \\
\text { 03.14.979 E - } \\
\text { Lat/Long: } 17^{\circ} 222^{\prime} 21^{\prime \prime} \\
\text { S / 466' } 34^{\prime \prime} \mathrm{W}\end{array}$ & $\begin{array}{l}\text { Recuperação da área com plantio } \\
\text { de mudas; alocação de poleiros. } \\
\text { Plantio de } 1.4464 \text { mudas de } 39 \\
\text { espécie. }\end{array}$ & $\begin{array}{l}2^{\circ} \text { sem.: monitoramento } \\
\text { das plantas. }\end{array}$ & $\begin{array}{lr}\text { Córrego roa } \\
\text { Esperança / } \\
\text { do Pacia } \\
\end{array}$ \\
\hline 6 & Marta Neiva & $\begin{array}{l}\text { Chácara do Céu / } \\
\text { (38) 36718516 / } \\
9117-1822 \quad \text { (Carlos } \\
\text { Neiva) }\end{array}$ & 0,5 & 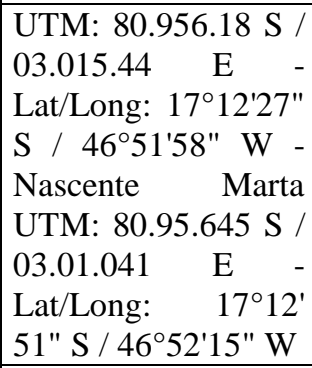 & $\begin{array}{l}\text { Recuperação da área com plantio } \\
\text { de mudas de espécies nativas. } \\
\text { Plantio de } 487 \text { mudas de } 34 \\
\text { espécie. }\end{array}$ & $\begin{array}{l}2^{\circ} \text { sem.: monitoramento } \\
\text { das plantas. }\end{array}$ & $\begin{array}{lr}\text { Córrego } & \text { São } \\
\text { Domingos / } & \text { Micro } \\
\text { bacia do } & \text { São } \\
\text { Domingos / } & \text { Bacia } \\
\text { do Paracatu. } & \end{array}$ \\
\hline 7 & $\begin{array}{l}\text { Miguel Angelo de } \\
\text { Almeida Marques }\end{array}$ & (38) 99491245 & 3,0 & $\begin{array}{l}\text { UTM: } 80.95 .950 \mathrm{~S} / \\
02.924 .04 \mathrm{E} /- \\
\text { Lat/Long: } 17^{\circ} 12^{\prime} 43^{\prime \prime} \\
\mathrm{S} / 46^{\circ} 57^{\prime} 07^{\prime \prime} \mathrm{W}\end{array}$ & $\begin{array}{l}\text { Recuperação da área com plantio } \\
\text { de mudas de espécies nativas. } \\
\text { Plantio de } 1.4464 \text { mudas de } 39 \\
\text { espécie. }\end{array}$ & $\begin{array}{l}2^{\circ} \text { sem.: monitoramento } \\
\text { das plantas. }\end{array}$ & $\begin{array}{l}\text { Nascente do Rio } \\
\text { Espalha / Micro } \\
\text { bacia do Espalha / } \\
\text { Bacia do Paracatu }\end{array}$ \\
\hline 8 & Nelci Alves Correa & Chácara Sonho Meu & 0,5 & $\begin{array}{l}\text { UTM: } 80.970 .21 \mathrm{~S} / \\
\text { 03.030.18 E } \\
\text { Lat/Long: } \\
\text { 17'12'10"S } \\
\text { 46 } 51^{\circ} 08^{\prime \prime} \mathrm{W}\end{array}$ & 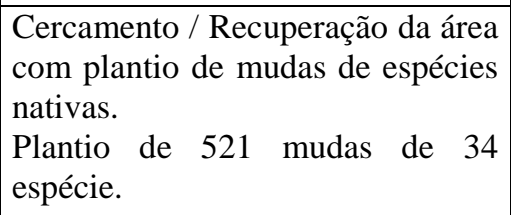 & $\begin{array}{l}2^{\circ} \text { sem.: monitoramento } \\
\text { das plantas. }\end{array}$ & $\begin{array}{lr}\text { Córrego } & \text { São } \\
\text { Domingos / } & \text { Micro } \\
\text { bacia do } & \text { São } \\
\text { Domingos / } & \text { Bacia } \\
\text { do Paracatu. } & \end{array}$ \\
\hline 9 & $\begin{array}{lll}\text { Nicolau } & \text { Antônio } & \text { de } \\
\text { Oliveira } & & \\
\end{array}$ & $\begin{array}{ll}\text { Fazenda } & \text { São } \\
\text { Domingos , } & \text { (38) } \\
3671-3710 & \end{array}$ & 0,5 & $\begin{array}{l}\text { UTM: } 03.02 .914 \mathrm{~S} / \\
\text { 80.97.516 E - } \\
\text { Lat/Long: } 17^{\circ} 11^{\prime} 54^{\prime \prime} \\
\text { S / } 46^{\circ} 51^{\prime} 11^{\prime \prime} \mathrm{W}\end{array}$ & $\begin{array}{l}\text { Cercamento / Recuperação da área } \\
\text { com plantio de mudas de espécies } \\
\text { nativas / Placa na ponte com o } \\
\text { córrego. } \\
\begin{array}{l}\text { Plantio de } 495 \text { mudas de } 34 \\
\text { espécie. }\end{array}\end{array}$ & $\begin{array}{l}2^{\circ} \text { sem.: monitoramento } \\
\text { das plantas. }\end{array}$ & $\begin{array}{lr}\text { Córrego } & \text { São } \\
\text { Domingos / } & \text { Micro } \\
\text { bacia do ra } & \text { São } \\
\text { Domingos / } & \text { Bacia } \\
\text { do Paracatu. } & \end{array}$ \\
\hline 10 & Paulo Sabonge & Cascalheira Sabonga & 3,0 & $\begin{array}{l}\text { UTM 80.95.295 S / } \\
\text { 03.20.089 E - } \\
\text { Lat/Long: } 17^{\circ} 21^{\prime} 95^{\prime \prime} \\
\text { S / } 46^{\circ} 69^{\prime} 16^{\prime \prime} \mathrm{W}\end{array}$ & $\begin{array}{l}\text { Recuperação da área com plantio } \\
\text { de mudas de espécies nativas. } \\
\text { Plantio de } 4.954 \text { mudas de } 57 \\
\text { espécie. }\end{array}$ & $\begin{array}{l}2^{\circ} \text { sem.: monitoramento } \\
\text { das plantas. }\end{array}$ & $\begin{array}{l}\text { Córrego do Ouro / } \\
\text { Bacia do Paracatu }\end{array}$ \\
\hline
\end{tabular}




\begin{tabular}{|c|c|c|c|c|c|c|c|}
\hline 11 & $\begin{array}{l}\text { Silvio Vieira Diniz (Fotos } \\
\text { - Anexo 2) }\end{array}$ & $\begin{array}{llr}\text { Fazenda } & \text { Pouso } \\
\text { Alegre/ } & \text { (38) } & 3671 \\
5262 & & \\
\end{array}$ & 3,0 & $\begin{array}{|lr|}\text { UTM: 81.143.95 S / } \\
\text { 02.844.65 e } & - \\
\text { Lat./Long: } & \\
\text { 1702'40"S } & \\
\text { 46'51'58" W } & \\
\end{array}$ & $\begin{array}{l}\text { Recuperação da área com plantio } \\
\text { de mudas de espécies nativas. } \\
\text { Plantio de } 3.906 \text { mudas de } 45 \\
\text { espécie. }\end{array}$ & $\begin{array}{l}2^{\circ} \text { sem. } \\
\text { Obs: falta atualizar os } \\
\text { dados. }\end{array}$ & $\begin{array}{lr}\text { Córrego } & \text { Santa } \\
\text { Isabel / } & \text { Bacia do } \\
\text { Paracatu } & \end{array}$ \\
\hline 12 & Udeir Alves Correa & $\begin{array}{ll}\text { Chácara } & \text { São } \\
\text { Domingos / (38) } \\
8808-7513\end{array}$ & 0,5 & $\begin{array}{|lrl|}\text { UTM: } 80.970 .21 & \mathrm{~S} / \\
\text { 03.030.18 } & \mathrm{E} & - \\
\text { Lat/Long: } & & \\
\text { 17²12'10"S } & & / \\
46^{\circ} 51^{\prime} 08^{\prime \prime} \mathrm{W} & & \end{array}$ & $\begin{array}{l}\text { Recuperação da área com plantio } \\
\text { de mudas de espécies nativas. } \\
\text { Plantio de } 656 \text { mudas de } 34 \\
\text { espécie. }\end{array}$ & $\begin{array}{l}2^{\circ} \text { sem. } \\
\text { Obs: falta atualizar os } \\
\text { dados. }\end{array}$ & $\begin{array}{lr}\text { Córrego do } & \text { São } \\
\text { Domingos / } & \text { Micro } \\
\text { bacia do } & \text { São } \\
\text { Domingos/ } & \text { Bacia } \\
\text { do Paracatu. } & \end{array}$ \\
\hline
\end{tabular}




\section{4 - RELATÓRIOS DOS PLANTIOS EM PARACATU (MG)}

\section{Fazenda Tangará, área de extração de cascalho}

Proprietário: Alcino Xavier Borges

Período: 08 de Fevereiro de 2008 (plantio)

\section{Objetivo}

Realizar recuperação de área degradada pela extração de cascalho procurando o máximo de diversidade (mix de espécies) com prioridade para espécies nativas do bioma Cerrado, na Fazenda Tangará, propriedade de Alcindo Xavier Borges, em Paracatu, MG.

\section{Caracterização da área}

Área de 2,5 ha utilizada para mineração de cascalho, anteriormente na condição natural de cerrado sensu stricto sobre Cambissolo com, cascalho.

\section{plantio}

Para a recuperação da área, foi estabelecida uma parceria com o proprietário.

O plantio de mudas foi realizado com espaçamento de $3 \mathrm{~m} \times 3 \mathrm{~m}$ (Figura 1), totalizando 2,5 ha. As covas foram feitas com trator, medindo 40x40x60.

Foram utilizadas 42 espécies, principalmente de cerrado sensu stricto e algumas frutíferas exóticas e espécies da Floresta Atlântica, totalizando 2.329 mudas.
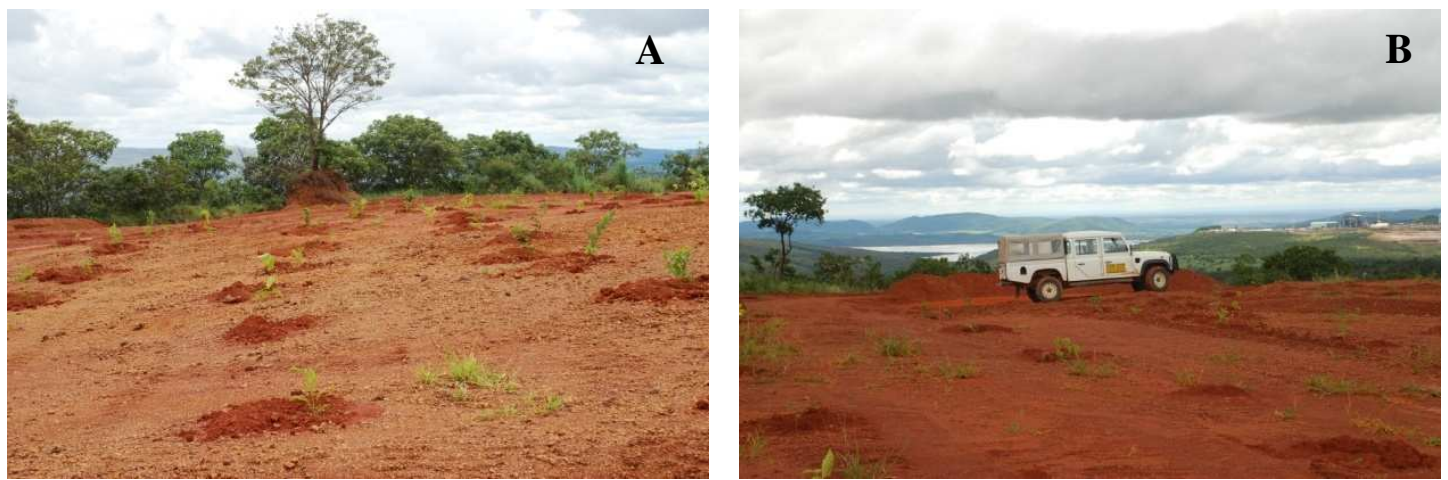

Figura 2. Plantio com espécies nativas do bioma Cerrado, realizado com espaçamento de $3 \mathrm{~m}$ x $3 \mathrm{~m}$, para a recuperação de cascalheira da Fazenda Tangará, Paracatu, Minas Gerais. A. Detalhe da situação de degradação da área, com destaque ao fundo do nível de rebaixamento do terreno por exploração do solo (Fonte: CRAD/UnB). B. Detalhe das linhas de plantios (Fonte: CRAD/UnB). 


\section{Fazenda Draga Três Rios}

\section{Mineração de areia Draga Três Rios}

Proprietário: Alcindo Xavier Borges

\section{Experimento}

Banco de Sementes Resistentes: avaliação de sobrevivência e desenvolvimento de banco de sementes de espécies arbóreas em diferentes estações do ano e em diferentes condições ambientais.

Período: 02 e 03 de Maio de 2008 (plantio)

\section{Caracterização da área}

Área de mineração de areia, com 3 ha, anteriormente com condição natural de cerrado sensu stricto sobre Neossolo Quartzarênico (areia).

\section{Justificativa}

Estabelecimento de um banco de sementes de espécies pioneiras arbóreas de áreas secas (banco de sementes resistentes) em plantio próximo do final das chuvas para acelerar o processo de restauração em área de mineração de areia.

\section{Objetivo}

Testar a possibilidade de iniciar o processo de restauração em diferentes épocas do ano nas condições de mineração de areia.

\section{Metodologia}

- Delineamento experimental:

- Dez blocos com 100 covas cada, com o plantio de cinco sementes de Lobeira (Solanum lycocarpum A.St.-Hil.), por cova com espaçamento de $2 \mathrm{~m}$ x $1 \mathrm{~m}$.

Cada bloco foi identificado com estaca do lado esquerdo e com o plantio de uma muda de Embaúba (Cecropia pachystachya Trécul.).

Entre cada cova foram plantadas duas sementes de Feijão-guandu (Cajanus sp.).

- Dez blocos com 100 covas cada, com o plantio de cinco sementes de Angicomonjolo (Acacia polyphylla DC.), por cova com espaçamento de $2 \mathrm{~m}$ x $1 \mathrm{~m}$.

Cada bloco foi identificado com estaca do lado esquerdo e com o plantio de uma muda de Angico-monjolo (Acacia polyphylla DC.).

Entre cada cova foram plantadas duas sementes de Feijão-guandu (Cajanus sp.). 
- Entre os blocos foram semeadas sementes de Angico-monjolo (Acacia polyphylla $\mathrm{DC}$.).
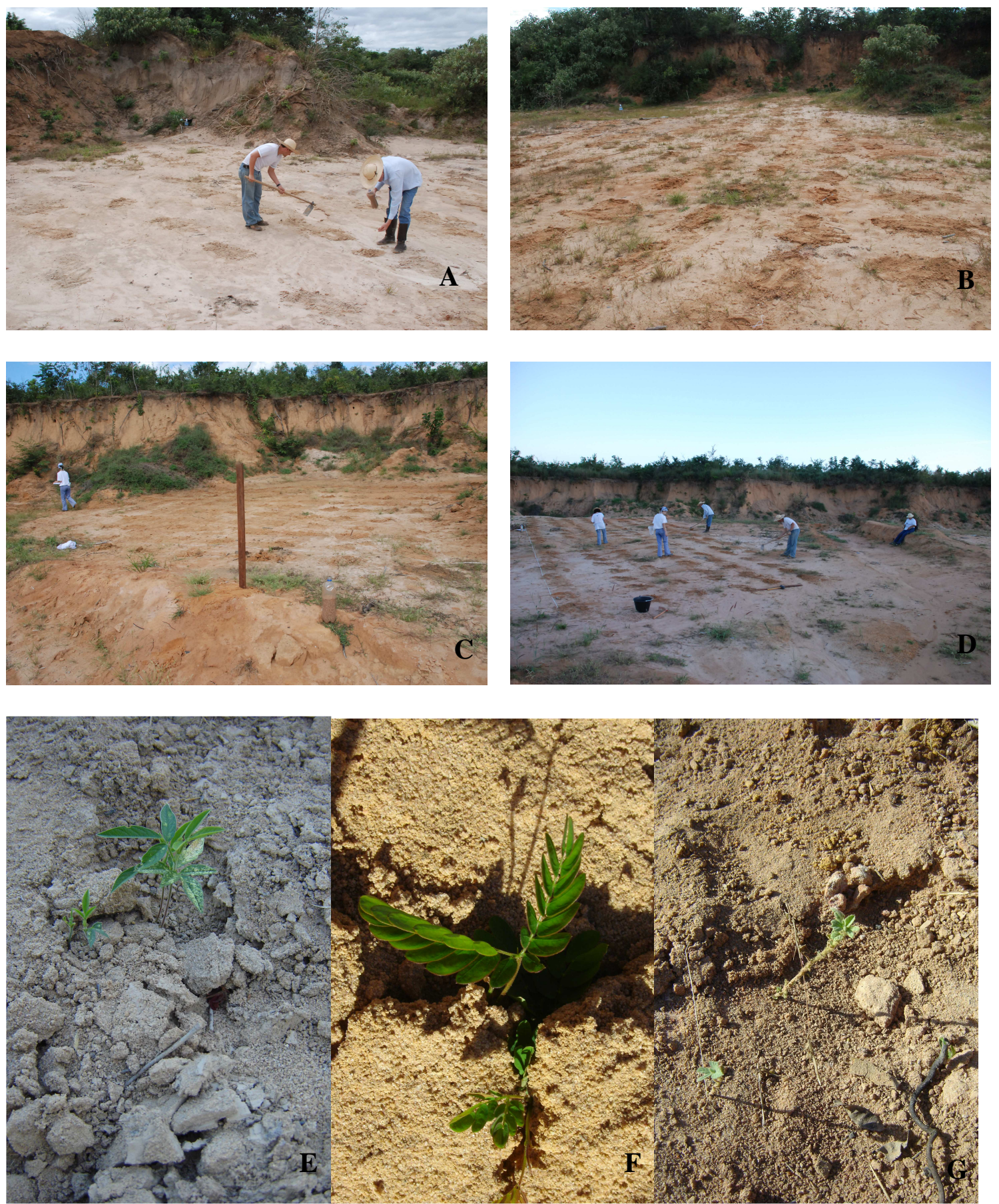

Figura. 3. Plantio de sementes de Lobeira (Solanum lycocarpum A.St.-Hil.) e Angicomonjolo (Acacia polyphylla DC.) para o estabelecimento de banco de sementes na área de extração de areia Draga Três Rios, Paracatu - MG. e área com Germinação de Feijão-guandu, Angico-monjolo e Lobeira no banco de sementes implementado, A. Detalhe plantio de semente de Lobeira, B. Detalhe plantio de semente de Angicomonjolo, C. Detalhe plantio de semente de Lobeira, D. Detalhe plantio de semente de Angico-monjolo e no banco de sentes: E. Germinação de Feijão-guandu, F. Germinação de Angico-monjolo, G. Geminação de Lobeira. 


\section{Fazenda Novo Horizonte}

\section{Proprietária: Márcia Sanders}

Período: 11 de Fevereiro de 2008 (plantio)

\section{Objetivo}

Realizar plantio de recuperação de área degradada por pasto, procurando o máximo de diversidade (mix de espécies) com prioridade para espécies nativas do bioma Cerrado, na Fazenda Novo Horizonte, propriedade de Márcia Sanders, em Paracatu, MG.

\section{Caracterização da área}

Área de 4,5 ha de pasto abandonado no entorno de barragem, anteriormente na condição natural de cerrado sensu stricto sobre Latossolo.

\section{Plantio}

Para a recuperação da área, foi estabelecida uma parceria com a proprietária.

O plantio de espécies foi realizado com espaçamento de $4 \mathrm{~m}$ x $4 \mathrm{~m}$ (Figura 1), em 4,92 ha. As covas foram feitas com trator, medindo 40x40x60.

Foram utilizadas 39 espécies, principalmente espécies de cerrado e algumas frutíferas exóticas e espécies da Floresta Atlântica, totalizando 1.503 plantas.

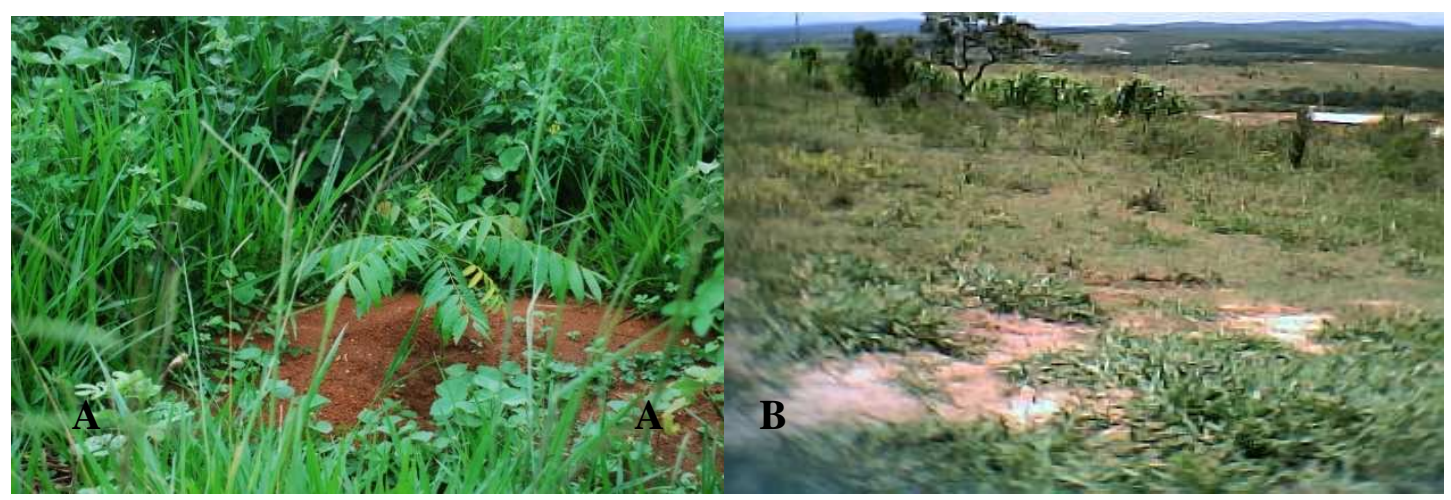

Figura 4. Área na Fazenda Novo Horizonte com plantio de mudas, espaçamento de 4 m x 4 m, para a recuperação da área. A. Detalhe de plantio em pasto abandonado, e B. Vista de paisagem de pasto para plantio de espécies nativas. 


\section{Fazenda Mão Fechada}

\section{Proprietários: João e Valéria Pimentel Barbosa Lucas}

Período: 17 a 19 de Março de 2008 (plantio).

\section{Objetivo}

Realizar recuperação de área degradada pela retirada de cascalho através do plantio de espécies nativas do bioma Cerrado, como espécies de cerrado sensu stricto, pioneiras, mata de galeria, mata seca e transição para a recuperação de uma área na Fazenda Mão Fechada, propriedade de seu João e Valéria, em Paracatu, MG.

\section{Caracterização da área}

Área de 1 ha com solo concrecionado (com formação de concreções lateríticas) na borda de mata de galeria, anteriormente recoberto por cerrado sensu stricto onde foi retirado cascalho.

\section{Plantio}

Para a realização da recuperação da área foi estabelecida uma parceria com os proprietários, que providenciaram o cercamento e o coveamento da área, com cova circular confeccionada com auxílio de trator e perfuratriz de $40 \mathrm{~cm}$ de diâmetro e $40 \mathrm{~cm}$ de profundidade.

Em cada cova, com tratamento segundo o pelo Centro de Conservação da Natureza e Recuperação de Áreas Degradadas - CRAD/UnB. Com espaçamento de $3 \mathrm{~m}$ x 3 m, foi feita adubação orgânica com esterco de gado (2 L por cova) e 100g de NPK (4-30-16). As mudas de plantas nativas que foram distribuídas ao longo das covas e em seguida plantadas.
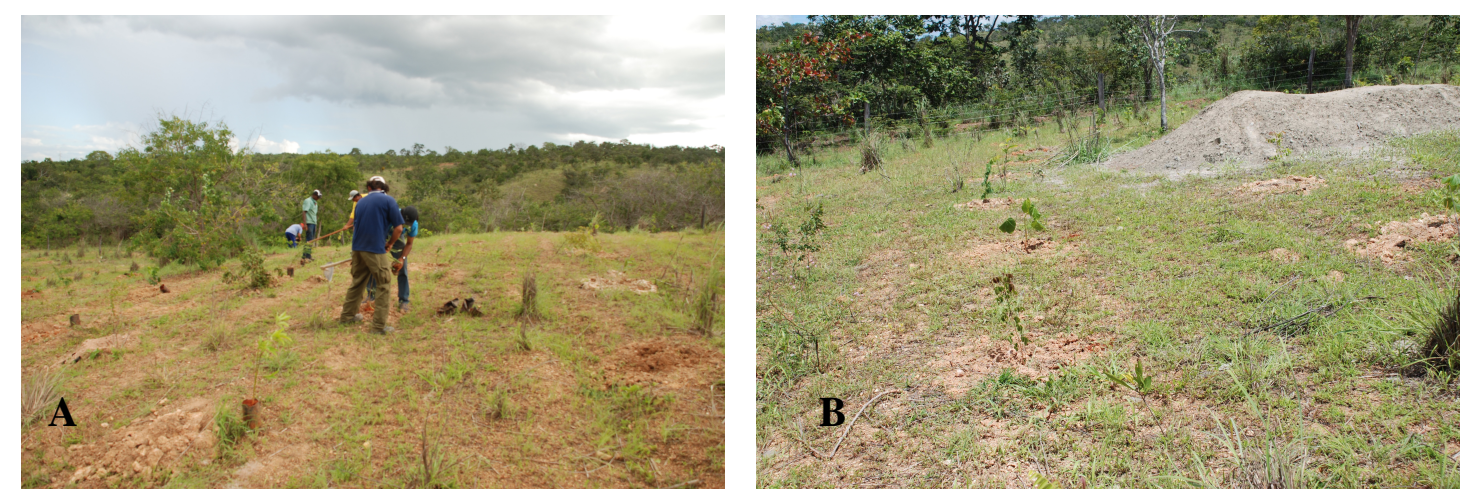

Figura 5. Plantio de mudas para recuperação de área degradada na Fazenda Mão

Fechada. A. Plantio de mudas nativas variadas. B. Área sendo preparada para plantio de espécies nativas da região. 
Quadro 3. Delineamento amostral utilizado para o plantio de recuperação de área degradada de cerrado sensu stricto na Fazenda Mão Fechada, de propriedade de João e Valéria Pimentel Barbosa Lucas, localizada em Paracatu, MG.

\begin{tabular}{|c|c|c|c|c|c|c|}
\hline \multicolumn{7}{|l|}{ BLOCO 1} \\
\hline Tratamento 5 & Angico vermelho & Ingá & Angico monjolo & Caixeta & Embaúba & Mutamba \\
\hline Tratamento 2 & Maria pobre & Pau formiga & Amburana & Chichá & Aroeira & Cedro \\
\hline Tratamento 4 & Albizia & Mata cachorro & Gonçalo alves & Sobre & Açoita cavalo & Baru \\
\hline Tratamento 1 & Camboatá & Pau d'oleo & Capituva & Apeiba & Capitão & Jatobá Mata \\
\hline Tratamento 3 & Cagaita & Tinguí & Vinhático & Sucupira branca & Pequi & Jatobá Cerrado \\
\hline \multicolumn{7}{|l|}{ BLOCO 2} \\
\hline Tratamento 3 & Cagaita & Tinguí & Vinhático & Sucupira branca & Pequi & Jatobá Cerrado \\
\hline Tratamento 1 & Camboatá & Pau d'oleo & Capituva & Apeiba & Capitão & Jatobá Mata \\
\hline Tratamento 4 & Albizia & Mata cachorro & Gonçalo alves & Sobre & Açoita cavalo & Baru \\
\hline Tratamento 2 & Maria pobre & Pau formiga & Amburana & Chichá & Aroeira & Cedro \\
\hline Tratamento 5 & Angico vermelho & Ingá & Angico monjolo & Caixeta & Embaúba & Mutamba \\
\hline \multicolumn{7}{|l|}{ BLOCO 3} \\
\hline Tratamento 4 & Albizia & Mata cachorro & Gonçalo alves & Sobre & Açoita cavalo & Baru \\
\hline Tratamento 3 & Cagaita & Tinguí & Vinhático & Sucupira branca & Pequi & Jatobá Cerrado \\
\hline Tratamento 5 & Angico vermelho & Ingá & Angico monjolo & Caixeta & Embaúba & Mutamba \\
\hline Tratamento 1 & Camboatá & Pau d'oleo & Capituva & Apeiba & Capitão & Jatobá Mata \\
\hline Tratamento 2 & Maria pobre & Pau formiga & Amburana & Chichá & Aroeira & Cedro \\
\hline \multicolumn{7}{|l|}{ BLOCO 4} \\
\hline Tratamento 1 & Camboatá & Pau d'oleo & Capituva & Apeiba & Capitão & Jatobá Mata \\
\hline Tratamento 2 & Maria pobre & Pau formiga & Amburana & Chichá & Aroeira & Cedro \\
\hline Tratamento 4 & Albizia & Mata cachorro & Gonçalo alves & Sobre & Açoita cavalo & Baru \\
\hline Tratamento 3 & Cagaita & Tinguí & Vinhático & Sucupira branca & Pequi & Jatobá Cerrado \\
\hline Tratamento 5 & Angico vermelho & Ingá & Angico monjolo & Caixeta & Embaúba & Mutamba \\
\hline
\end{tabular}




\section{Chácara São Domingo}

\section{Proprietários: Udeir Alves Correia}

Período: 16 a 24 de Dezembro de 2008 (plantio)

\section{Objetivo}

Realizar recuperação de área degradada pela pastagem através do plantio de espécies nativas do bioma Cerrado, como espécies de cerrado sensu stricto, mata de galeria e mata seca, para a recuperação de uma área na Chácara São Domingo, propriedade de Senhor Udeir Alves Correia, em Paracatu, MG.

\section{Caracterização da área}

Área de 0,8 ha de pastagem sendo anteriormente uma mata ciliar, com características entorno de cerrado sensu stricto sobre Latossolo Vermelho.

\section{Plantio}

Em cada cova, com espaçamento de $3 \mathrm{~m} \times 3 \mathrm{~m}$, foi feita adubação orgânica com esterco de gado (2 L por cova) e 100g de NPK (4-30-16). As mudas foram distribuídas ao longo das covas e em seguida plantadas. As covas foram feitas com trator, medindo $40 \times 40 \times 60$.

Foram plantadas 487 mudas de 34 espécies diferentes de forma aleatória em toda área;

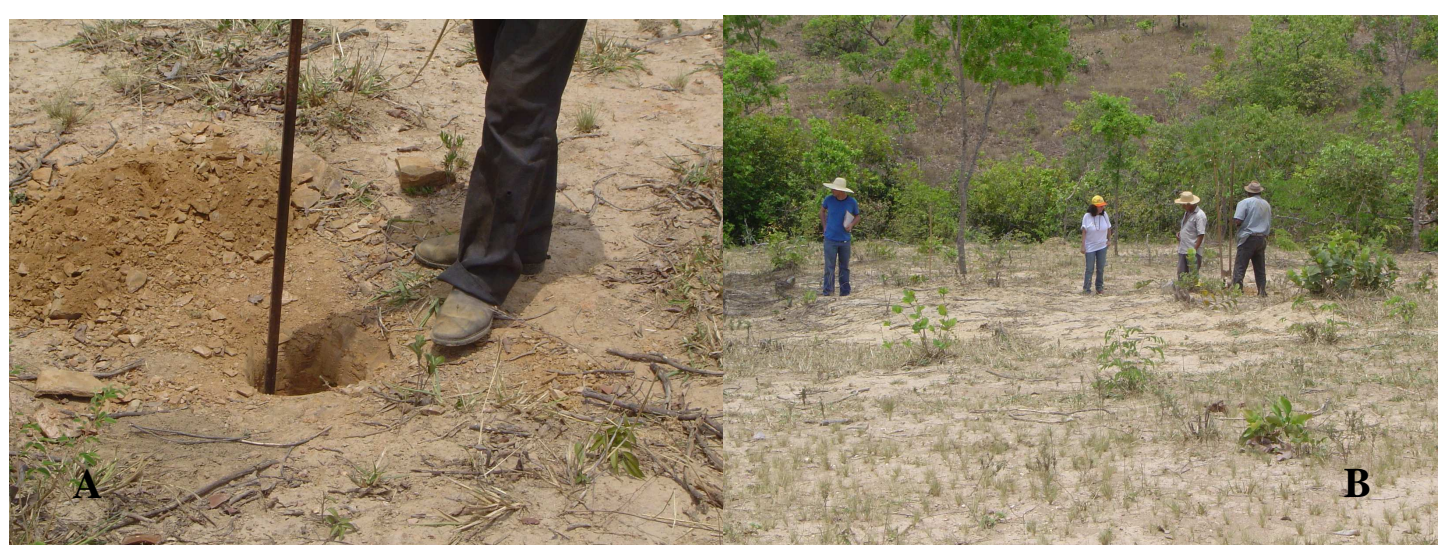

Figura 6. Plantio de mudas para recuperação de área alterada na Chácara São Domingo, Paracatu - MG. A. Cova confeccionada com alavanca de ponta com diâmetro 15 cm., B. Área a ser plantada com plantas nativas da região. 


\section{Chácara do Céu}

\section{Proprietários: Marta Neiva}

Período: 16 a 24 de Dezembro de 2008 (plantio)

\section{Objetivo}

Realizar recuperação de área degradada pela pastagem através do plantio de espécies nativas do bioma Cerrado, como espécies de cerrado sensu stricto, mata de galeria e mata seca, para a recuperação de uma área na Chácara do céu, propriedade de Senhor Marta Neiva, em Paracatu, MG.

\section{Caracterização da área}

Área de 0,5 ha de pastagem sendo anteriormente uma mata ciliar, com características entorno de cerrado sensu stricto sobre Latossolo Vermelho.

\section{Plantio}

Em cada cova, com espaçamento de $3 \mathrm{~m}$ x $3 \mathrm{~m}$, foi feita adubação orgânica com esterco de gado curtido ( 2 L por cova) e 100g de NPK (4-30-16). As mudas foram distribuídas ao longo das covas e em seguida plantadas. As covas foram feitas com trator, medindo 40x40x60.

Foram plantadas 487 mudas de 34 espécies diferentes de forma aleatória em toda área;

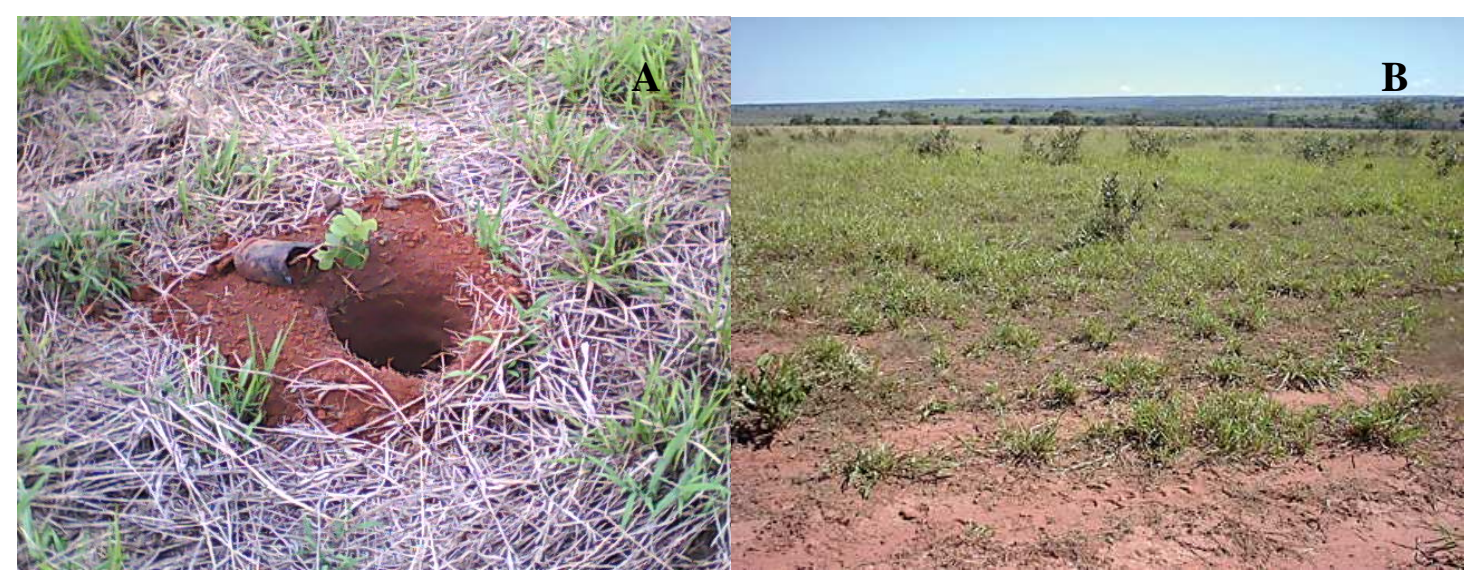

Figura 7. Plantio de mudas para recuperação de área alterada na Marta Neiva, Paracatu - MG. A. Cova preparada para receber a muda de planta nativa. B. Área que será preparada para plantio de plantas nativas da região. 


\section{Fazenda Sonho Meu}

\section{Proprietários: Nelcir}

Período: 16 a 24 de Dezembro de 2008 (plantio)

\section{Objetivo}

Realizar recuperação de área degradada pela pastagem através do plantio de espécies nativas do bioma Cerrado, como espécies de cerrado sensu stricto, mata de galeria e mata seca, para a recuperação de uma área na Fazenda Sonho Meu, propriedade de Senhor Nelcir Alves Correa, em Paracatu, MG.

\section{Caracterização da área}

Área de 0,6 ha de pastagem sendo anteriormente uma mata ciliar, com características entorno de cerrado sensu stricto sobre Latossolo amarelo.

\section{Plantio}

Em cada cova, com espaçamento de $3 \mathrm{~m}$ x $3 \mathrm{~m}$, foi feita adubação orgânica com esterco de gado curtido (2 L por cova) e 100g de NPK (4-30-16).

Foram plantadas 521 mudas de 34 espécies diferentes de forma aleatória em toda área;

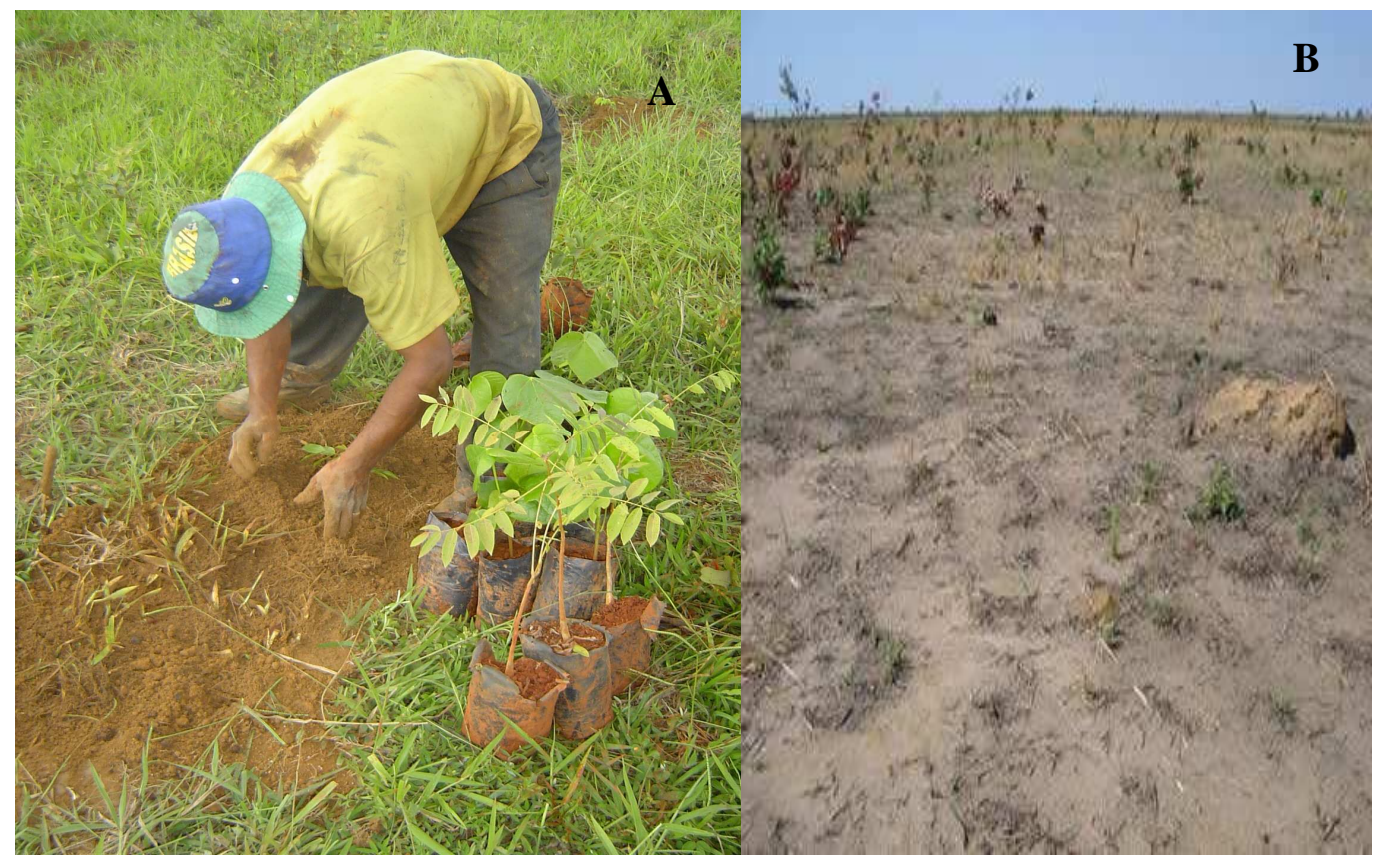

Figura 8. Plantio de mudas para recuperação de área alterada na Fazenda Sonho Meu, Paracatu - MG. A. Plantio de muda nativa da região. B. Área degradada que será recuperada com plantas nativas da região. 


\section{Fazenda São Domingo}

\section{Proprietários: Nicolau Antônio Oliveira}

Período: 16 a 24 de Dezembro de 2008 (plantio)

\section{Objetivo}

Realizar recuperação de área degradada pela pastagem através do plantio de espécies nativas do bioma Cerrado, como espécies de cerrado sensu stricto, mata de galeria, mata seca, transição e espécies pioneiras para a recuperação de uma área na Fazenda São Domingo, propriedade de Senhor Nicolau Antônio de Oliveira, em Paracatu, MG.

\section{Caracterização da área}

Área de 0,5 ha de pastagem sendo anteriormente uma mata ciliar, com características entorno de cerrado sensu stricto sobre Latossolo amarelo.

\section{Plantio}

Em cada cova, com espaçamento de $3 \mathrm{~m}$ x $3 \mathrm{~m}$, foi feita adubação orgânica com esterco de gado curtido (2 L por cova) e 100g de NPK (4-30-16). As covas foram feitas com trator, medindo 40x40x60.

- Foram plantadas 495 mudas de 34 espécies diferentes de forma aleatória em toda área;

- Parte desta área foi feito o plantio no curso de extensão com alunos do curso técnico em Meio Ambiente da Universidade Tecnológica -UNITEC (Paractu-MG).

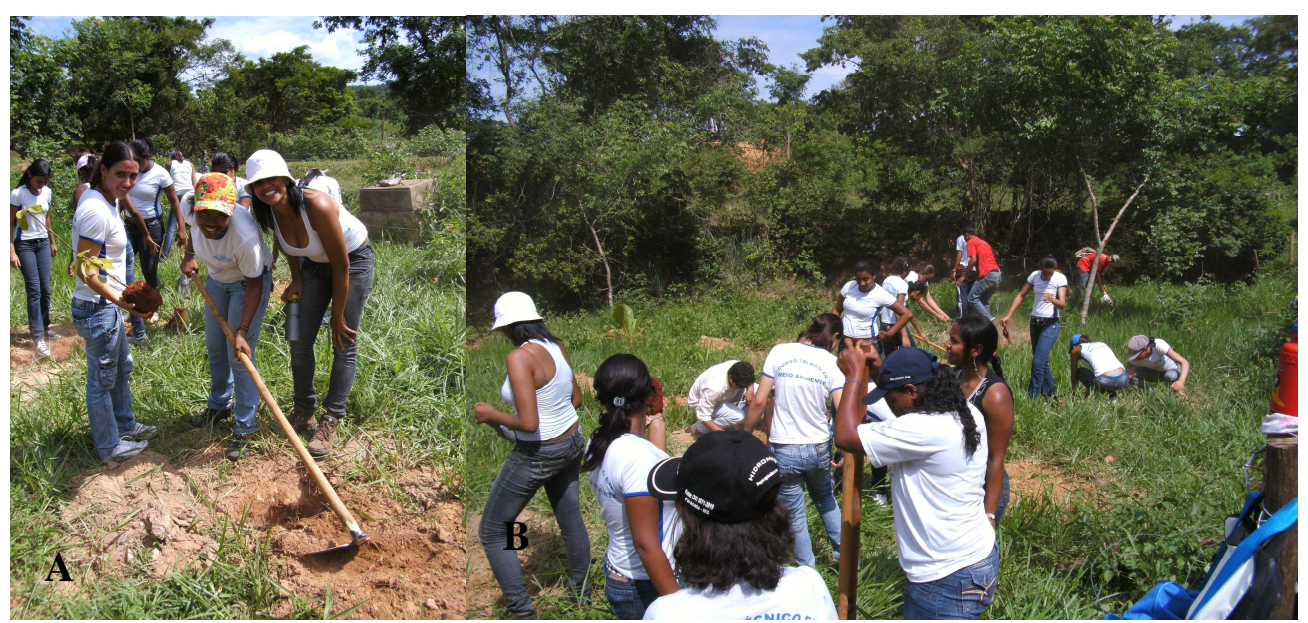

Figura 9. Plantio de mudas para recuperação de área alterada na Fazenda São Domingo, Paracatu - MG. A. Mutirão com alunas da UNITEC (Paracatu-MG), plantando mudas nativas da região. B. Área sendo plantada com plantas nativas da região por mutirão de alunas da UNITEC (Paracatu-MG). 


\section{Fazenda Pouso Alegre}

\section{Proprietários: Silvio Vieira Diniz}

Período: 06 a 12 de Janeiro de 2009 (plantio)

\section{Objetivo}

Realizar recuperação de área degradada pela pastagem através do plantio de espécies nativas do bioma Cerrado, como espécies de cerrado sensu stricto, mata de galeria e mata seca, para a recuperação de uma área na Fazenda Pouso Alegre, propriedade de seu Silvio Vieira Diniz, em Paracatu, MG.

\section{Caracterização da área}

Área de 4 ha de pastagem entorno de uma área úmida (vereda), com características entorno de cerrado sensu stricto sobre Latossolo vermelho.

\section{Plantio}

Em cada cova, com espaçamento de $3 \mathrm{~m}$ x $3 \mathrm{~m}$, foi feita adubação orgânica com esterco de gado ( 2 L por cova) e 100g de NPK (4-30-16). As covas foram feitas com trator, medindo 40x40x60.

Foram plantadas 3.363 mudas de 46 espécies diferentes de forma aleatória em toda área;

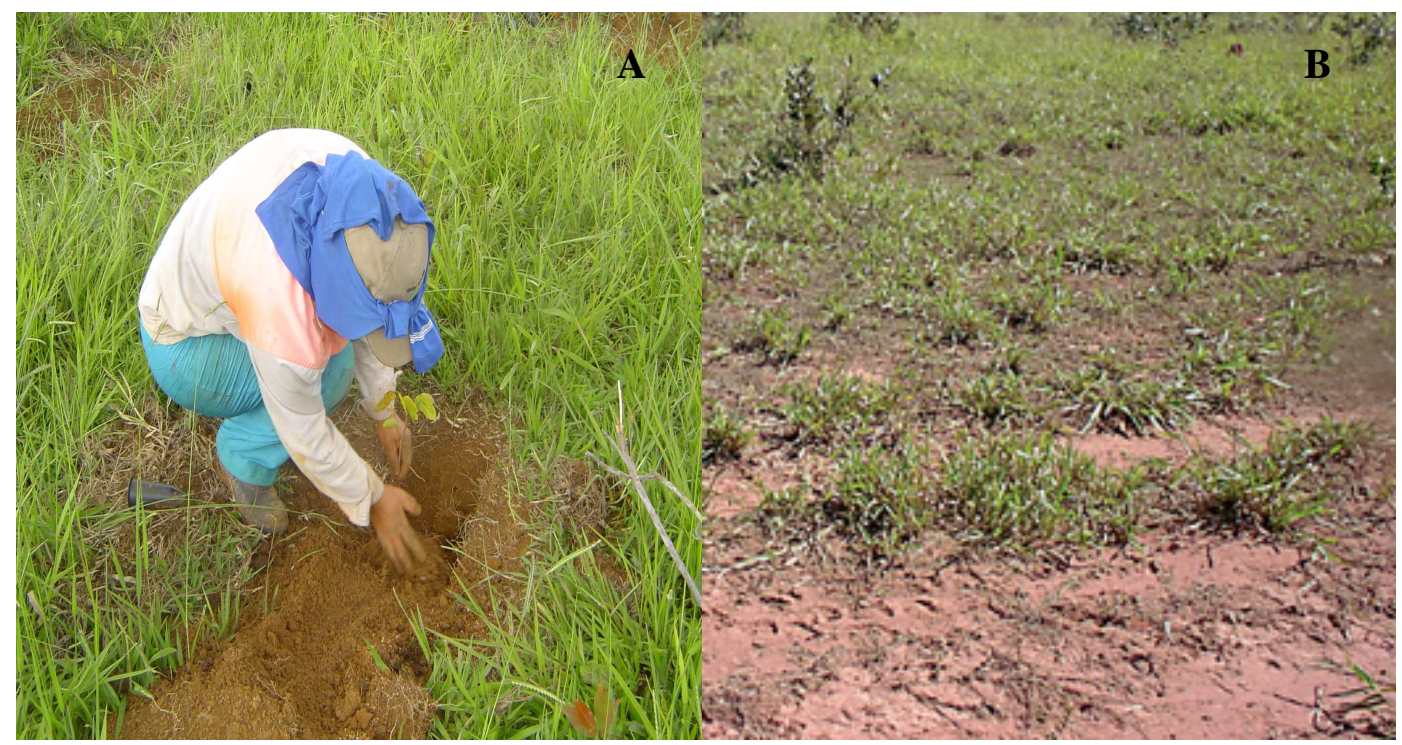

Figura 10. Plantio de mudas para recuperação de área alterada na Fazenda Pouso Alegre, Paracatu - MG. A. Plantio de planta nativa para recuperar pasto abandonado. B. Área de pasto abandonado a ser recuperado com plantas nativas da região. 


\section{Experimento}

Junto com o plantio de recuperação foi instalado o experimento onde foram 30 espécies, sendo 6 de cada formação, Cerrado Sensu Stricto, mata de galeria e mata seca com 15 indivíduos de cada espécie dividido em 5 blocos e 3 repetições. Totalizando assim 450 mudas para esse experimento.

Quadro 4. Delineamento amostral, utilizando 5 blocos; 30 espécies e três repetições para recuperação de áreas degradadas na Fazenda Pouso Alegre do Sr. Silvio Vieira Diniz, em Paracatu, MG.

\begin{tabular}{|c|c|c|c|c|c|c|}
\hline \multicolumn{7}{|l|}{ BLOCO 1} \\
\hline Tratamento 1 & Camboatá & Pau d'oleo & Capituva & Apeiba & Capitão & Jatobá da mata \\
\hline Tratamento 2 & Caroba & Pau formiga & Amburana & Chichá & Aroeira & Cedro \\
\hline Tratamento 3 & Cagaita & Tinguí & Vinhático & Paineira & Pau santo & Faveira \\
\hline Tratamento 4 & Albizia & Mata cachorro & Gonçalo alves & Ipê amarelo & Açoita cavalo & Baru \\
\hline Tratamento 5 & Angico vermelho & Jenipapo & Angico monjolo & Caixeta & Embaúba & Mutamba \\
\hline \multicolumn{7}{|l|}{ BLOCO 2} \\
\hline Tratamento 2 & Caroba & Pau formiga & Amburana & Chichá & Aroeira & Cedro \\
\hline Tratamento 3 & Cagaita & Tinguí & Vinhático & Paineira & Pau santo & Faveira \\
\hline Tratamento 4 & Albizia & Mata cachorro & Gonçalo alves & Ipê amarelo & Açoita cavalo & Baru \\
\hline Tratamento 5 & Angico vermelho & Jenipapo & Angico monjolo & Caixeta & Embaúba & Mutamba \\
\hline Tratamento 1 & Camboatá & Pau d'oleo & Capituva & Apeiba & Capitão & Jatobá da mata \\
\hline \multicolumn{7}{|l|}{ BLOCO 3} \\
\hline Tratamento 3 & Cagaita & Tinguí & Vinhático & Paineira & Pau santo & Faveira \\
\hline Tratamento 4 & Albizia & Mata cachorro & Gonçalo alves & Ipê amarelo & Açoita cavalo & Baru \\
\hline Tratamento 5 & Angico vermelho & Jenipapo & Angico monjolo & Caixeta & Embaúba & Mutamba \\
\hline Tratamento 1 & Camboatá & Pau d'oleo & Capituva & Apeiba & Capitão & Jatobá da mata \\
\hline Tratamento 2 & Caroba & Pau formiga & Amburana & Chichá & Aroeira & Cedro \\
\hline \multicolumn{7}{|l|}{ BLOCO 4} \\
\hline Tratamento 4 & Albizia & Mata cachorro & Gonçalo alves & Ipê amarelo & Açoita cavalo & Baru \\
\hline Tratamento 5 & Angico vermelho & Jenipapo & Angico monjolo & Caixeta & Embaúba & Mutamba \\
\hline Tratamento 1 & Camboatá & Pau d'oleo & Capituva & Apeiba & Capitão & Jatobá da mata \\
\hline Tratamento 2 & Caroba & Pau formiga & Amburana & Chichá & Aroeira & Cedro \\
\hline Tratamento 3 & Cagaita & Tinguí & Vinhático & Paineira & Pau santo & Faveira \\
\hline \multicolumn{7}{|l|}{ BLOCO 5} \\
\hline Tratamento 5 & Angico vermelho & Jenipapo & Angico monjolo & Caixeta & Embaúba & Mutamba \\
\hline Tratamento 1 & Camboatá & Pau d'oleo & Capituva & Apeiba & Capitão & Jatobá da mata \\
\hline Tratamento 2 & Caroba & Pau formiga & Amburana & Chichá & Aroeira & Cedro \\
\hline Tratamento 3 & Cagaita & Tinguí & Vinhático & Paineira & Pau santo & Faveira \\
\hline Tratamento 4 & Albizia & Mata cachorro & Gonçalo alves & Ipê amarelo & Açoita cavalo & Baru \\
\hline
\end{tabular}




\section{Fazenda Espalha}

\section{Proprietários: Miguel Angelo}

Período: 19 a 23 de Janeiro de 2009 (plantio)

\section{Objetivo}

Realizar recuperação de área degradada pela pastagem através do plantio de espécies nativas do bioma Cerrado, como espécies de cerrado sensu stricto, mata de galeria, mata seca, transição e espécies pioneiras para a recuperação de uma área na Fazenda Espalha, propriedade de Senhor Miguel Ângelo, em Paracatu, MG.

\section{Caracterização da área}

Área de 4 ha de pastagem onde ocorre afloração do lençol freático, com características entorno de cerrado sensu stricto sobre Latossolo vermelho.

\section{Plantio}

Em cada cova, com espaçamento de $3 \mathrm{~m}$ x $3 \mathrm{~m}$, foi feita adubação orgânica com esterco de gado (2 L por cova) e 100g de NPK (4-30-16). As mudas foram distribuídas ao longo das covas e em seguida plantadas.

O plantio foi realizado de forma aleatória, onde foram usados as seguintes espécies, sendo 3.363 mudas de 50 espécies diferentes.

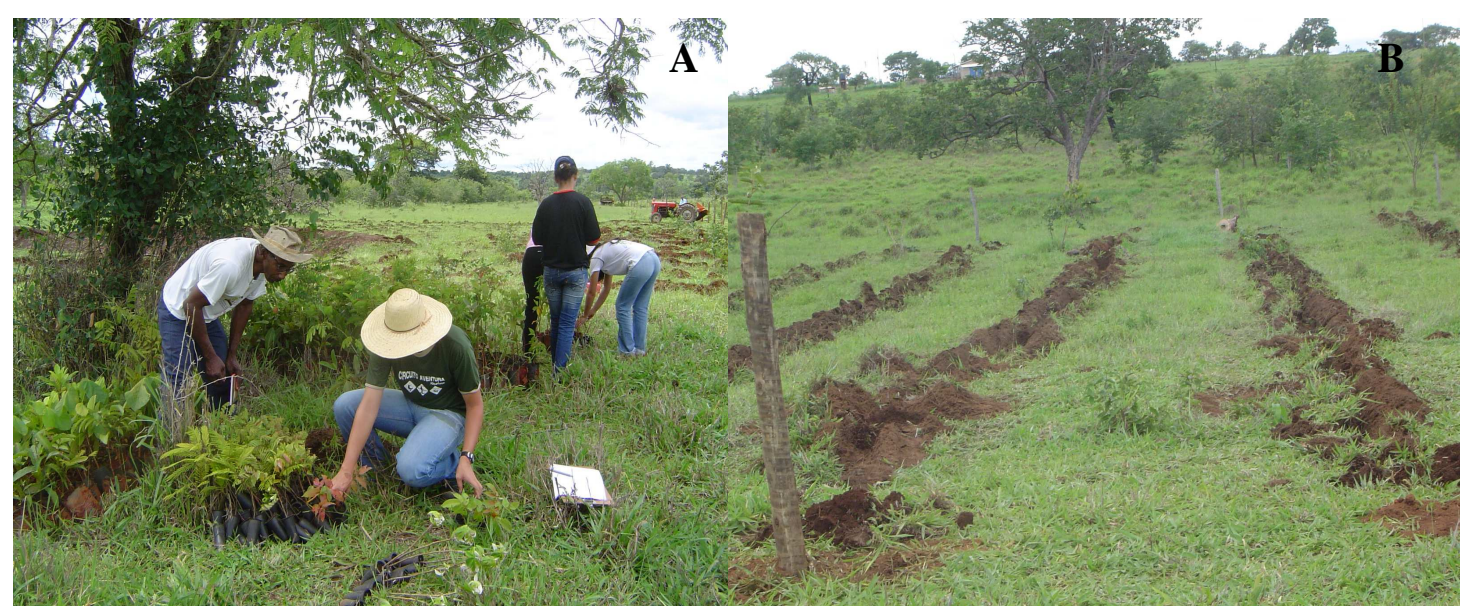

Figura 11. Plantio de mudas para recuperação de área alterada na Fazenda Espalha, Paracatu - MG. A. Distribuição de mudas nativas nas covas. B. Área pronta para ser plantadas com espécies nativas da região. 


\section{Experimento}

Junto com o plantio de recuperação foi instalado o experimento onde foram 30 espécies, sendo 6 de cada formação, com 15 indivíduos de cada espécie dividido em 5 blocos e 3 repetições. Totalizando assim 450 mudas para esse experimento.

Quadro 5. Delineamento amostral, utilizando 5 blocos; 30 espécies e três repetições para recuperação de áreas degradadas na Fazenda do Sr. Miguel Angelo, em Paracatu, MG.

\begin{tabular}{|c|c|c|c|c|c|c|}
\hline \multicolumn{7}{|l|}{ BLOCO 1} \\
\hline Tratamento 1 & Camboatá & Pau d'oleo & Capituva & Apeiba & Capitão & Jatobá da mata \\
\hline Tratamento 2 & Caroba & Pau formiga & Amburana & Chichá & Aroeira & Cedro \\
\hline Tratamento 3 & Cagaita & Tinguí & Vinhático & Paineira & Pau-santo & Faveira \\
\hline Tratamento 4 & Albizia & Mata cachorro & Gonçalo alves & Ipê amarelo & Açoita cavalo & Baru \\
\hline Tratamento 5 & Angico vermelho & Ingá & Angico monjolo & Caixeta & Embaúba & Mutamba \\
\hline \multicolumn{7}{|l|}{ BLOCO 2} \\
\hline Tratamento 2 & Caroba & Pau formiga & Amburana & Chichá & Aroeira & Cedro \\
\hline Tratamento 3 & Cagaita & Tinguí & Vinhático & Paineira & Pau-santo & Faveira \\
\hline Tratamento 4 & Albizia & Mata cachorro & Gonçalo alves & Ipê amarelo & Açoita cavalo & Baru \\
\hline Tratamento 5 & Angico vermelho & Ingá & Angico monjolo & Caixeta & Embaúba & Mutamba \\
\hline Tratamento 1 & Camboatá & Pau d'oleo & Capituva & Apeiba & Capitão & Jatobá da mata \\
\hline \multicolumn{7}{|l|}{ BLOCO 3} \\
\hline Tratamento 3 & Cagaita & Tinguí & Vinhático & Paineira & Pau-santo & Faveira \\
\hline Tratamento 4 & Albizia & Mata cachorro & Gonçalo alves & Ipê amarelo & Açoita cavalo & Baru \\
\hline Tratamento 5 & Angico vermelho & Ingá & Angico monjolo & Caixeta & Embaúba & Mutamba \\
\hline Tratamento 1 & Camboatá & Pau d'oleo & Capituva & Apeiba & Capitão & Jatobá da mata \\
\hline Tratamento 2 & Caroba & Pau formiga & Amburana & Chichá & Aroeira & Cedro \\
\hline \multicolumn{7}{|l|}{ BLOCO 4} \\
\hline Tratamento 4 & Albizia & Mata cachorro & Gonçalo alves & Ipê amarelo & Açoita cavalo & Baru \\
\hline Tratamento 5 & Angico vermelho & Ingá & Angico monjolo & Caixeta & Embaúba & Mutamba \\
\hline Tratamento 1 & Camboatá & Pau d'oleo & Capituva & Apeiba & Capitão & Jatobá da mata \\
\hline Tratamento 2 & Caroba & Pau formiga & Amburana & Chichá & Aroeira & Cedro \\
\hline Tratamento 3 & Cagaita & Tinguí & Vinhático & Paineira & Pau-santo & Faveira \\
\hline \multicolumn{7}{|l|}{ BLOCO 5} \\
\hline Tratamento 5 & Angico vermelho & Ingá & Angico monjolo & Caixeta & Embaúba & Mutamba \\
\hline Tratamento 1 & Camboatá & Pau d'oleo & Capituva & Apeiba & Capitão & Jatobá da mata \\
\hline Tratamento 2 & Caroba & Pau formiga & Amburana & Chichá & Aroeira & Cedro \\
\hline Tratamento 3 & Cagaita & Tinguí & Vinhático & Paineira & Pau-santo & Faveira \\
\hline Tratamento 4 & Albizia & Mata cachorro & Gonçalo alves & Ipê amarelo & Açoita cavalo & Baru \\
\hline
\end{tabular}




\section{Cascalheira Sabonja}

\section{Proprietários: Paulo Sabonja}

Período: 12 a 16 de Fevereiro de 2009 (plantio)

\section{Objetivo}

Realizar recuperação de área degradada em área de empréstimo de cascalho através do plantio de espécies nativas do bioma Cerrado, como espécies de cerrado sensu stricto, mata de galeria, mata seca, transição e espécies pioneiras para a recuperação de uma área na Cascalheira do Paulo Sabonja, propriedade do Senhor Paulo Sabonja, em Paracatu, MG.

\section{Caracterização da área}

Área de 4 ha de exploração de cascalho, com características entorno de cerrado sensu stricto sobre Cambissolo.

\section{Plantio}

Em cada cova, com espaçamento de $3 \mathrm{~m}$ x $3 \mathrm{~m}$, foi feita adubação orgânica com esterco de gado (2 L por cova) e 100g de NPK (4-30-16). As mudas foram distribuídas ao longo das covas e em seguida plantadas.

O plantio foi realizado de forma aleatória, onde foram usados as seguintes espécies, sendo 4.954 mudas de 57 espécies diferentes.

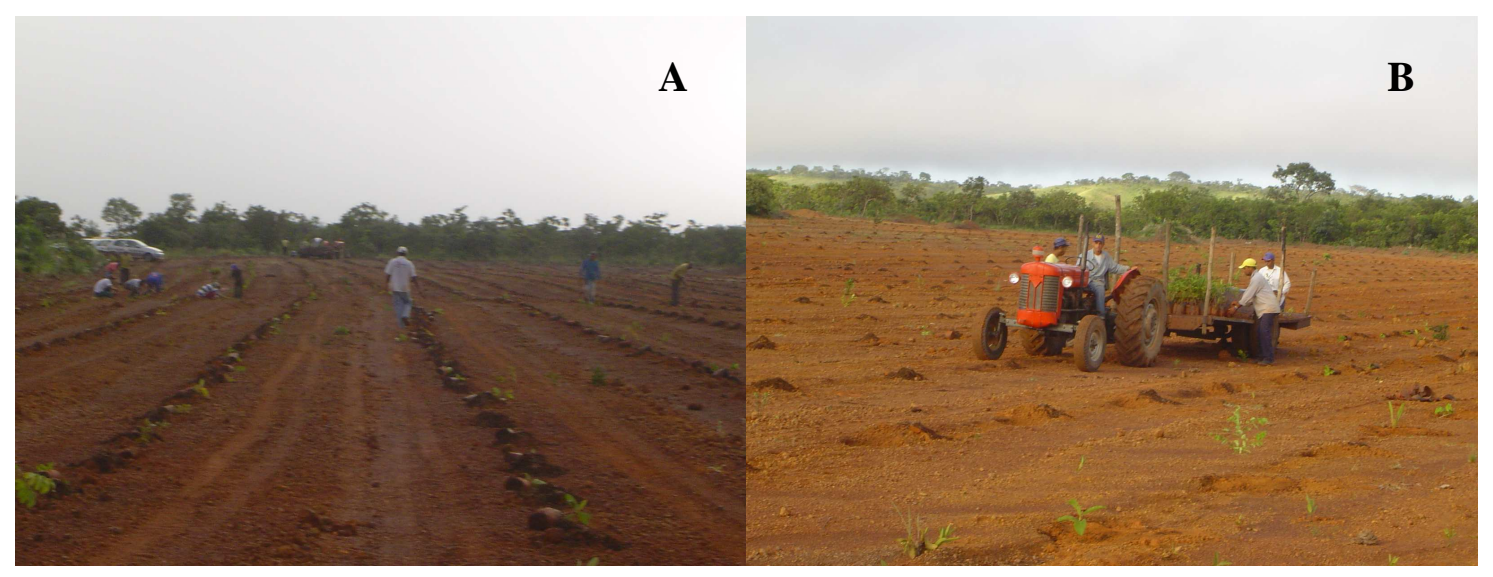

Figura 12. Plantio de mudas para recuperação de área alterada na Cascalheira do Sabonja, Paracatu - MG. A. Distribuição de plantas nativas em fileiras. B. Plantio de plantas nativas com uso de trator na distribuição. 


\section{Cascalheira Marcia Sanders}

\section{Proprietários: Marcia Sanders}

Período: 07 a 11 de Fevereiro de 2009 (plantio)

\section{Objetivo}

Realizar recuperação de área degradada em área de empréstimo de cascalho através do plantio de espécies nativas do bioma Cerrado, como espécies de cerrado sensu stricto, mata de galeria, mata seca, transição e espécies pioneiras para a recuperação de uma área na Cascalheira do Marcia Sanders, propriedade do Senhora Marcia Sanders, em Paracatu, MG.

\section{Caracterização da área}

Área de 4 ha de exploração de cascalho, com características entorno de cerrado sensu stricto sobre Cambissolo.

\section{Plantio}

Em cada cova, com espaçamento de $3 \mathrm{~m}$ x $3 \mathrm{~m}$, foi feita adubação orgânica com esterco de gado (2 L por cova) e 100g de NPK (4-30-16). As mudas foram distribuídas ao longo das covas e em seguida plantadas.

O plantio foi realizado de forma aleatória, onde foram usados as seguintes espécies, sendo 4.149 mudas de 62 espécies diferentes.

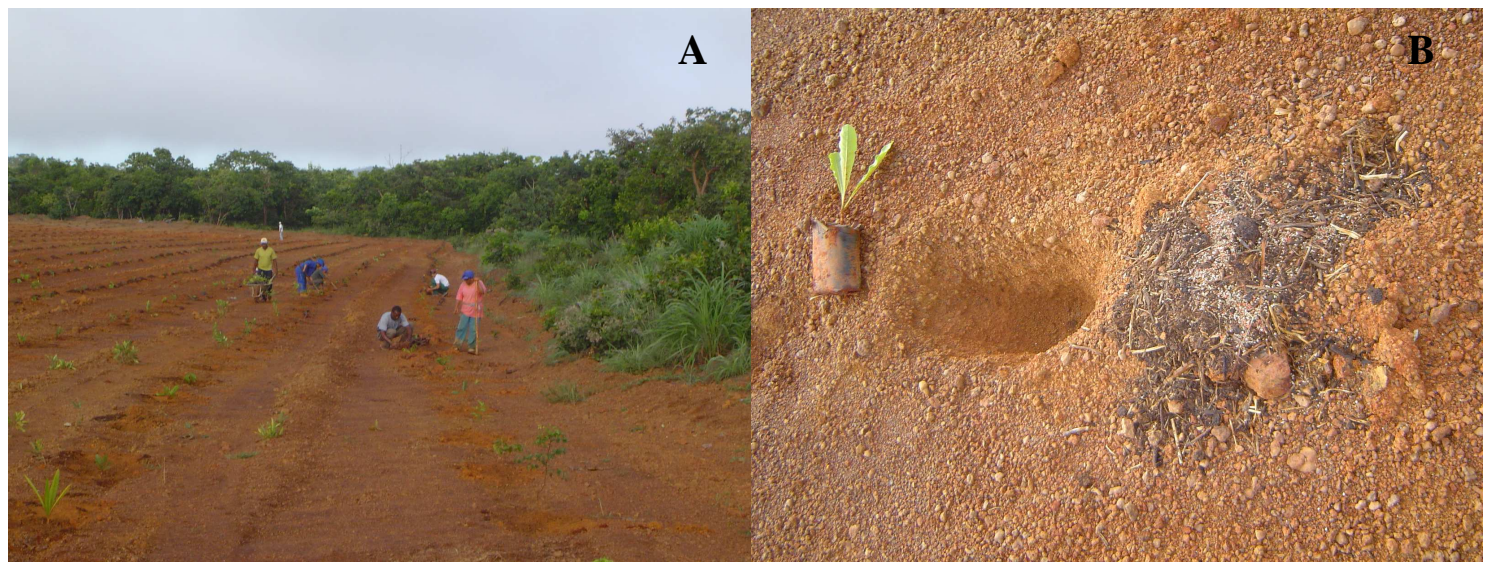

Figura 13. Plantio de mudas para recuperação de área alterada na Cascalheira da Marcia Sanders, Paracatu - MG. A. Área sendo recuperada com plantas nativas. B. Cova preparada com muda de planta nativa da região. 


\section{Experimento}

Junto com o plantio de recuperação foi instalado o experimento onde foram 30 espécies, sendo 6 de cada formação, com 15 indivíduos de cada espécie dividido em 5 blocos e 3 repetições. Totalizando assim 450 mudas para esse experimento.

Quadro 6. Delineamento amostral, utilizando 5 blocos; 30 espécies e três repetições para recuperação de áreas degradadas na Fazenda do Sr. Paulo Sabonja, em Paracatu, MG.

\begin{tabular}{|c|c|c|c|c|c|c|}
\hline \multicolumn{7}{|l|}{ BLOCO 1} \\
\hline Tratamento 1 & Camboatá & Pau d'oleo & Paineira & Ipê verde & Jerivá & Jatobá da mata \\
\hline Tratamento 2 & Caroba & Pau ferro & Pombo & Bico de pato & Aroeira & Cabo de machado \\
\hline Tratamento 3 & Araticum & Mama cadela & Vinhático & Murici & Pau terra & Mangaba \\
\hline Tratamento 4 & Marmelada & Mata cachorro & Gonçalo alves & Ipê amarelo & Sucupira preta & Baru \\
\hline Tratamento 5 & Angico vermelho & Ingá & Ipê Rosa & Ipê roxo & Embaúba & Mutamba \\
\hline \multicolumn{7}{|l|}{ BLOCO 2} \\
\hline Tratamento 2 & Caroba & Pau ferro & Pombo & Bico de pato & Aroeira & Cabo de machado \\
\hline Tratamento 3 & Araticum & Mama cadela & Vinhático & Murici & Pau terra & Mangaba \\
\hline Tratamento 4 & Marmelada & Mata cachorro & Gonçalo alves & Ipê amarelo & Sucupira preta & Baru \\
\hline Tratamento 5 & Angico vermelho & Ingá & Ipê Rosa & Ipê roxo & Embaúba & Mutamba \\
\hline Tratamento 1 & Camboatá & Pau d'oleo & Paineira & Ipê verde & Jerivá & Jatobá da mata \\
\hline \multicolumn{7}{|l|}{ BLOCO 3} \\
\hline Tratamento 3 & Araticum & Mama cadela & Vinhático & Murici & Pau terra & Mangaba \\
\hline Tratamento 4 & Marmelada & Mata cachorro & Gonçalo alves & Ipê amarelo & Sucupira preta & Baru \\
\hline Tratamento 5 & Angico vermelho & Ingá & Ipê Rosa & Ipê roxo & Embaúba & Mutamba \\
\hline Tratamento 1 & Camboatá & Pau d'oleo & Paineira & Ipê verde & Jerivá & Jatobá da mata \\
\hline Tratamento 2 & Caroba & Pau ferro & Pombo & Bico de pato & Aroeira & Cabo de machado \\
\hline \multicolumn{7}{|l|}{ BLOCO 4} \\
\hline Tratamento 4 & Marmelada & Mata cachorro & Gonçalo alves & Ipê amarelo & Sucupira preta & Baru \\
\hline Tratamento 5 & Angico vermelho & Ingá & Ipê Rosa & Ipê roxo & Embaúba & Mutamba \\
\hline Tratamento 1 & Camboatá & Pau d'oleo & Paineira & Ipê verde & Jerivá & Jatobá da mata \\
\hline Tratamento 2 & Caroba & Pau ferro & Pombo & Bico de pato & Aroeira & Cabo de machado \\
\hline Tratamento 3 & Araticum & Mama cadela & Vinhático & Murici & Pau terra & Mangaba \\
\hline \multicolumn{7}{|l|}{ BLOCO 5} \\
\hline Tratamento 5 & Angico vermelho & Ingá & Ipê Rosa & Ipê roxo & Embaúba & Mutamba \\
\hline Tratamento 1 & Camboatá & Pau d'oleo & Paineira & Ipê verde & Jerivá & Jatobá da mata \\
\hline Tratamento 2 & Caroba & Pau ferro & Pombo & Bico de pato & Aroeira & Cabo de machado \\
\hline Tratamento 3 & Araticum & Mama cadela & Vinhático & Murici & Pau terra & Mangaba \\
\hline Tratamento 4 & Marmelada & Mata cachorro & Gonçalo alves & Ipê amarelo & Sucupira preta & Baru \\
\hline
\end{tabular}




\section{5 - Outros projetos do CRAD}

Vários projetos relacionados ao Centro de Referência em Conservação da Natureza e Recuperação de Áreas Degradadas CRAD/UnB estão em andamento, contando com recursos financeiros (custeio, capital e bolsas). Dentre os projetos em andamento referentes às atividades que estão aglutinadas pelo $\mathrm{CRAD/UnB}$, e que contam com apoio financeiro, destacam-se:

1 - Título: Centro de Referência em Conservação da Natureza e Recuperação de Áreas Degradadas - bioma Cerrado, parte priorizada pela Shell a partir do projeto: Berço das Águas, métodos e estratégias participativas para recuperação de áreas degradadas no Distrito Federal.

Objetivo: Implementação de Centro de Referência em Conservação da Natureza e Recuperação de Áreas Degradadas. Aproximadamente metade da estrutura física do Centro será implantada com recursos já disponibilizados pelo MMA/CODEVASF, do Programa de Revitalização da Bacia do Rio São Francisco.

Instituição Proponente: Universidade de Brasília - UnB.

Executor: Universidade de Brasília - UnB.

Financiador: Termo de ajustamento de conduta SHELL DO BRASIL e Ministério Publico do Distrito Federal - MP/DF.

Parcerias: Universidade de Brasília - Departamento de Engenharia Florestal Laboratório de Manejo Florestal, Instituto Estadual de Florestas - MG.

Período de execução: dez. de 2007 a dez. de 2008.

Valor do Financiamento: 500.000,00

Coordenadora do Projeto: Jeanine Maria Felfili. 
2 - Título: Restabelecimento da integridade ecológica e eco-gestão nas bacias São Francisco e Paranoá, DF.

Objetivo: Avaliar a integridade biológica nas bacias hidrográficas do São Francisco e Paranoá, como ferramenta para análise das condições ambientais, por meio do monitoramento e inventário da biota aquática e flora terrestre; selecionar áreas de referência de qualidade ambiental como parâmetros para recuperação de áreas degradadas; avaliar o status de conservação das espécies e ecossistemas; e através de atividades de educação ambiental propor a articulação do conhecimento e habilidades das comunidades com o embasamento teórico científico e tecnologias apropriadas à sustentabilidade ambiental, especialmente na recuperação da vegetação no Cerrado.

Instituição proponente: Instituto Vida Verde - IVV

Financiador: Fundo Nacional de Meio Ambiente - FNMA

Executor: Universidade de Brasília - UnB e Universidade Católica de Brasília -UCB.

Parcerias: Centro de Referência em Conservação da Natureza e Recuperação de Áreas Degradadas da Universidade de Brasília - CRAD/UnB, Associação Rural de Vargem Bonita, Associação Comunitária do Núcleo Rural Córrego do Palha e Empresa de Assistência Técnica e Extensão Rural - EMATER-DF.

Público alvo: Comunidade da Área de Proteção Ambiental do Gama e Cabeça de Veado.

Período de execução: 2005 - atual.

Valor do Financiamento: $\mathrm{R} \$ 500.000,00$.

Coordenadoras do Projeto: Jeanine Maria Felfili (UnB), Luciana Galvão (UCB), Claudia Padovesi (UnB).

Resultados alcançados: Implantação de módulos demonstrativos de recuperação de áreas degradadas, monitoramento de ecossistemas terrestres e aquáticos. 
3 - Título: Recuperação de áreas degradadas com participação comunitária na Bacia do Ribeirão do Gama na APA Gama e Cabeça de Veado, DF.

Objetivo: Recuperar as margens dos ribeirões do Gama, Mato Seco e Cedro (matas de galeria degradadas e/ou totalmente retiradas) e do Córrego da Onça na Bacia do Ribeirão do Gama; reduzir do assoreamento e poluição dos recursos hídricos e criação de corredores ecológicos; contribuir para a prevenção e combate a incêndios florestais; conscientizar e educar a comunidade com relação ao direito a um meio ambiente ecologicamente equilibrado e com relação à ecologia do cerrado, levando-os à adoção de meios de vida sustentáveis pelas comunidades de chácaras ribeirinhas e núcleos rurais.

Instituição Proponente: Universidade de Brasília - UnB.

Executor: Centro de Referência em Conservação da Natureza e Recuperação de Áreas Degradadas CRAD/UnB.

Financiador: Termo de ajustamento de conduta SHELL DO BRASIL-MP/DF.

Parcerias: Instituto Vida Verde, Universidade Católica de Brasília, EMATER-DF, Associações de produtores de Vargem Bonita e do Córrego da Onça, Associação Comunitária do Park Way e Centro Educacional de Vargem Bonita.

Período de execução: dez. de 2007 a dez. de 2008.

Valor do Financiamento: 100.000,00

Coordenadora do Projeto: Jeanine Maria Felfili. 
4 - Título: Centro de Referência em Recuperação de Áreas Degradadas na Bacia Hidrográfica do Rio São Francisco - CR-ad: Bioma Cerrado.

Objetivo: Implantar o Centro de Referência para a Recuperação de Áreas Degradadas (CR-ad), com a finalidade de estimular os proprietários rurais à proteção e recuperação da vegetação nativa da região da bacia hidrográfica do São Francisco, priorizando ações nas áreas de preservação permanente (APP) e de reserva legal (RL) e difundir experiências realizadas em sua região de abrangência (bioma correspondente); o Centro será também um difusor e catalizador de iniciativas, uma vez que este terá elementos para subsidiar as atividades de recuperação nas esferas públicas e privadas.

Financiador: Companhia de Desenvolvimento do Vale do São Francisco CODEVASF

Executor: Universidade de Brasília - UnB.

Parcerias: Universidade de Brasília - Departamento de Engenharia Florestal Laboratório de Manejo Florestal, Instituto Estadual de Florestas - IEF/MG.

Período de execução: dezembro de 2006 - atual.

Valor do Financiamento: $750.000,00$

Coordenadores do Projeto: Jeanine Maria Felfili 
5 - Título: Laudo biológico para a criação de uma Reserva Extrativista no município de Buritizeiro - MG e Laudo biológico para a criação de uma Reserva Extrativista na Comunidade Quilombola de Barra do Pacuí - MG.

Objetivo: Subsidiar com dados sobre a caracterização e conservação da vegetação em Buritizeiro e Barra do Pacuí para a criação de duas Reservas Extrativistas em Minas Gerais, visando atender a demanda de comunidades extrativistas para conservação dos recursos nestas regiões e da cultura local.

Público alvo: Comunidades extrativistas de Buritizeiros e Barra do Pacuí, em Minas Gerais.

Financiador: Ministério do Meio Ambiente (MMA) / Instituto Chico Mendes de Conservação da Biodiversidade (ICMBio)

Executor: ICMBio / CRAD/UnB e Laboratório de Manejo, Departamento de Engenharia Florestal

Parcerias: Centro de Referência em Conservação da Natureza e Recuperação de Áreas Degradadas - CRAD/UnB.

Período de execução: outubro de 2007 a julho de 2008

Coordenadores do Projeto: Jeanine Maria Felfili e Gustavo Henrique de Oliveira. 
6 - Título: Implantação e desenvolvimento de Ações no Centro de Referência em Recuperação de Áreas Degradadas e execução de ações de revitalização na Bacia do São Francisco, trecho Médio São Francisco no bioma Cerrado.

Objetivo: Implementação do Centro de Referência em Recuperação de Áreas Degradadas na Bacia Hidrográfica do Rio São Francisco (CR-ad) com base física no DF e em Paracatu - MG, agregando instalações e capacidades técnico-científicas da Universidade de Brasília e do Instituto Estadual de Florestas de Minas Gerais e com a participação do Comitê de Bacias do Paracatu e demais comitês que atuam no médio São Francisco nos limites do bioma Cerrado.

Financiador: Ministério do Meio Ambiente - MMA - Secretaria de Recursos Hídricos e Secretaria de Biodiversidade e Florestas - Plano Nacional de Florestas -PNF e o Programa de Revitalização do São Francisco.

Executor: Universidade de Brasília - UnB.

Parcerias: Instituto Estadual de Florestas - IEF/MG e Prefeitura Municipal de Paracatu, Comitê de Bacias Hidrográficas da Bacia do Paracatu, Fundação de Estudos e Pesquisas em Administração e Desenvolvimento, Instituto Vida Verde, Rede de Sementes do Cerrado, Instituto de Desenvolvimento Ambiental, Country Clube de Brasília, Clube da Semente.

Período de execução: janeiro de 2007 a dezembro de 2008.

Valor do Financiamento: 628.800,00

Coordenadores do Projeto: Jeanine Maria Felfili.

Resultados esperados: Estabelecimento de Modelos de Recuperação (MDR), com base em espécies nativas do bioma em pelo menos quatro condições representativas das principais ameaças que causam degradação à bacia; Cursos de capacitação; Disseminação de práticas de recuperação e Desenvolvimento sustentável. 


\section{CONCLUSÃO}

Diante do exposto foi possível disponibilizar as informações das atividades realizadas pelo Centro de Referência em Conservação da Natureza e Recuperação de Áreas Degradadas - CRAD/UnB, através da análise documental deste Centro Especializado, desde a sua criação, na Universidade de Brasília - UnB, até os projetos que foram implementados em recuperação de áreas degradadas, respondendo assim sua idealização, quais pesquisadores, institutos, faculdades e departamentos fazem parte e parcerias com o CRAD/UnB.

$\mathrm{O}$ resultado deste trabalho contribui na gestão da informação, possibilitando ao público em geral, em todos os níveis, acessar informações do CRAD/UnB, na recuperação de áreas degradadas do Bioma Cerrado, mostrando o tipo de aplicabilidade das técnicas que são adotadas em áreas de extração de cascalho, areia e de pastos abandonados, com os modelos com plantios de mudas de espécies nativas para os projetos na região de Paracatu-MG, Unaí - MG, Januária-MG e em Brasília-DF, focando o adequado tratamento, seguindo as orientação dos técnicos especializados na área.

O Centro Especializado disponibiliza suas ações na Universidade de Brasília para todas as instituições públicas, privadas e em todos os seguimentos educacionais ou para interessados em buscar informações sobre recuperação de áreas degradadas, através do sítio http://www.crad.unb.br, conta ainda com publicações permanentes de livros, cartilhas e folders. 


\section{CONSIDERAÇÕES FINAIS E RECOMENDAÇÕES}

As características da região ocupada por produtores rurais na sub-bacia do rio Paracatu, Bacia do São Francisco, em Paracatu - MG explicitam sua alta sensibilidade e importância ambiental e a necessidade de adoção de tecnologias de controle ambiental e de uso adequado do solo, proteção de nascentes e córregos, contribuição para a reversão do quadro atual de degradação da vegetação do Cerrado e minimização dos impactos negativos na Bacia do São Francisco.

Por ser de fundamental importância a recuperação de áreas degradadas nas propriedades que fazem parte da Bacia do São Francisco, para a manutenção de ecossistemas do bioma Cerrado, faz-se necessário um plano de gestão ambiental em toda a região, a fim de implementar modelos de recuperação nas propriedades rurais e, principalmente, disciplinar a ocupação antrópica desordenada na região.

Por parte dos órgãos governamentais deveria ser disponibilizados recursos para serem aplicados em fundo de conservação do Cerrado, que poderiam ser destinados basicamente para três linhas de ação: manutenção das unidades de conservação existentes, ampliação do sistema de áreas protegidas para compatibilizar a proteção dos recursos naturais com a proteção dos recursos hídricos e a promoção da recuperação de áreas degradadas de modo a promover a reconexão das áreas nativas isoladas. A gestão deste fundo poderia ser feita por um conselho tripartite, constituído pelo Governo, pelo Setor Empresarial e pela Sociedade Civil Organizada.

Além dessa sugestão, indicamos algumas ações emergenciais que poderiam ser levadas a cabo pelo Governo Federal em articulação com os governos Estaduais e Municipais:

1. adotar uma postura de desmatamento zero para o Cerrado, pelo menos até que seja feito um planejamento integrado para a ocupação do bioma;

2. criar programas de recuperação de áreas degradadas como forma de compensar as áreas com desmatamento evitado.

A atuação conjunta de organizações e instituições civis, como as organizações não-governamentais, e ambientais podem contribuir, significativamente, para a sensibilização ambiental dos produtores rurais na região, principalmente, por meio de realizações de encontros que abordem as questões socioambientais. Desta forma, as 
informações aqui apresentadas não deixam dúvidas quanto à necessidade de ações que visem um planejamento e gestão ambiental na região, de forma multidisciplinar. Além de observar aspectos legais para fazer cumprir o estabelecido nas legislações correlatas as áreas degradadas a fim definir limites geográficos para recuperação da vegetação degradada.

Há ainda, a necessidade de implantação de um cadastro de propriedades rurais aliado a um banco de dados, que revele informações sobre os diversos aspectos de uso da terra. Este cadastro é de fundamental importância para a análise e o monitoramento ambiental da região. 


\section{REFERÊNCIAS BIBLIOGRÁFICAS}

AMARAL, S. A. Marketing e Desafio Profissional em Unidades de Informação. Vol.25, N³ (1996). Disponível em: http://revita.ibict.br/ciinf/index.php/ciinf/article/viewRST/452/411. Acesso em 17/04/2009.

AMARAL, S. A. Gestão da oferta de produtos e serviços das unidades de informação de Brasília no ambiente tradicional e no ciberespaço. Enancib, n. 5, 2003.

ANDRADE, L. A. Z.; FELFILI, J. M.; VIOLATTI, L. Fitossociologia de uma área de cerrado denso na RECOR-IBGE, Brasília-DF. Acta Botânica Brasílica, v. 16, n. 2 , p. 225-240, 2002.

ÂNGELO, J.G.; LENA, J.; DIAS, L.; SANTOS, J. Diversidade vegetal em áreas em reabilitação de mineração de ferro, na Minas da Alegria, em Mariana, MG. Revista Árvore, v. 26, p. 183-192, 2002.

ANTUNES, P. B. Direito ambiental. Rio de Janeiro: Lúmen Júris, 2005. 940 p.

ASSUNÇÃO, S. L. \& FELFILI, J. M. Fitossociologia de um fragmento de cerrado sensu stricto na APA do Paranoá, DF, Brasil. Acta Botânica Brasílica, v. 18, n. 4, p. 903-909, 2004.

Brasil. 1988. Constituição: República Federativa do Brasil. Brasília. Senado Federal, Centro Gráfico.

BRASIL. Lei Ordinária $n^{\circ}$ 9.985, de 18 de julho de 2000. Institui o Sistema Nacional de Unidades de Conservação da Natureza e dá outras providências. Diário Oficial da República Federativa do Brasil, 19 de julho de 2000.

CAldATO, S. L., Floss, P. A., CROCE, D. M., LONGHI, S. J. Estudo da regeneração natural, banco de sementes e chuva de sementes na reserva genética florestal de caçador, SC. Ciência Florestal, v. 6, n. 1, p.27-38, 1996.

CARNEIRO, J. W. P. et al. Gerenciamento da produção e do controle da qualidade de sementes de plantas forrageiras. In: Produção e utilização de pastagens. Maringá: C.P.A.F.,1997. 71 p. 
CORREA, A. A. M. Métodos de Combate à Erosão do Solo. Serviço de Informação Agrícola. Ministério da Agricultura. Rio de Janeiro, Série didática, n. 17, 1959.

CORREA, R. S. Degradação e Recuperação de Áreas no Distrito Federal. Ecologia e recuperação de áreas degradadas no serrado. Brasília, Paralelo, v. 15, p. 13-19, 1998.

COSTA, R. B.; SCARLOT, A. A fragmentação florestal e os recursos genéticos. In: COSTA, R. B. (Org.). Fragmentação florestal de desenvolvimento rural na região Centro-Oeste. Campos grande: 2003. p. 53-74.

EMBRAPA. Savanas tropicais. 2003. Disponível em: <http://www.cpac.embrapa.br/simposio/IIsavanastropicais/>. Acessado em novembro de 2008.

FARIAS, R. J. C.; CAMAPUM de Carvalho, J.; PALMEIRAS, E. M. \& SCHNEIDER, C. R. Técnica de baixo custo para controle e recuperação de ravinas e voçorocas. In: SALES et al. (org.). II SIMPÓSIO SOBRE SOLOS TROPICAIS E PROCESSOS EROSIVOS NO CENTRO-OESTE. 2005, Goiânia: p. 369-383.

FELFILI, J. M., SILVA JÚNIOR, M. C.; RESENDE, A. B.; MACHADO, J. W.B.; NOGUEIRA, P. E.; WALTER, S. M. T. Projeto Biogeografia do Bioma Cerrado: vegetação e solos. Cadernos de Geociências, v. 12, p. 84-114, 1994.

FELFILI, J. M.; RIBEIRO, J. W. B. Recuperação de matas de galeria. Planaltina: Embrapa Cerrado, 2000. p. 45.

FELFILI, J. M; SANTOS, A. A. B. Direito ambiental e subsídio para a revetação de áreas degradadas no Distrito Federal, v.4, n. 2, p.58, 2002.

FELFILI, J. M.; SILVA JÚNIOR., M. C.; BELTRÃO, L. \& SANTOS, A. A. B. Legislação ambiental. Brasília: CREA-DF, 2005. p. 114.

FEPAF. 2003. Restauração ecológica de ecossistemas naturais. Orgs. Paulo Yoshio Kageyama et. al. Botucatu. SP.

FRANCO, A. A.; CAMPELlO, E. F.; SILVA, E. R. et al. Revegetação de solos degradados. EMBRAPA, CNPAB, Comunicado Técnico, v. 9, 1992, 9 p.

IBGE - INSTITUTO BRASILEIRO DE GEOGRAFIA. Disponível em: <http://www.ibge.gov.br>. Acessado em novembro de 2008. 
KLINK, C. A. \& MACHADO, R. A Conservação do Cerrado Brasileiro. Megadiversidade, v. 1, n. 1, 2005.

MAGAlHÃES, Juraci Perez. A evolução do Direito Ambiental no Brasil. 2. ed. São Paulo: Juarez de Oliveira, 2002.

MENDONÇA, R.; FELFILI, J. M; WALTER, B. M. T.; SILVA JÚNIOR, M. C.; RESENDE, A. V.; FIGUEIRAS, T. S.; NOGUEIRA, P. E. Flora vascular do bioma Cerrado. In: SANO, S. M.; ALMEIDA, S. P. (Org.). Cerrado: ambiente e flora. Planaltina: Embrapa - Cerrado, 1998. p. 287-556.

Ministério da Agricultura. Recuperação do Cerrado. Serviço de Informação Agrícola, Rio de Janeiro, Estudos Brasileiros, n. 21, 1964.

MMA - MINISTÉRIO DO MEIO AMBIENTE. Categorias de Unidades de Conservação. 2006. Disponível em: <http://www.mma.gov.br/port/sbf/dap/ apbconc.html>. Acessado em novembro de 2008.

MMA. 2006. Lei da Vida: A lei dos crimes ambientais. Lei n. 9.605, de 12 de fevereiro de 1998 e Decreto n. 3.179, de 21 de setembro de 1999. MMA. IBAMA.

MMA. 2000. Sistema nacional de Unidades de Conservação da Natureza. SNUC: lei n. 9.985, de 18 de julho de 2000. Brasília: MMA/SBF, 2000.

MMA - MINISTÉRIO DO MEIO AMBIENTE. Fragmentação de Ecossistemas: Causas, efeitos sobre a biodiversidade e recomendações políticas públicas. Brasília, 2003.

MORENO, M. I. C. \& CARDOSO, E. Utilização do método twinspan na delimitação de formações vegetacionais do cerrado. Caminhos de Geografia, v. 16, n. 16, p. 108$116,2005$.

MORENO, M. I. C.; SCHIAVINI, I. Relação entre vegetação e solo em um gradiente florestal na Estação Ecológica do Panga, Uberlândia (MG). Revista Brasileira de Botânica, v. 24, n. 4, p. 537-544, 2001.

NOVAES, W.; RIBAS, D. \& NOVAES, P. C. Agenda 21 - Bases para discussão. Brasília: MMA/PNUD, 2000. 
OLIVEIRA FILHO, A. T. Estudos ecológicos da vegetação como subsídios para programas de revegetação com espécies nativas: uma proposta metodológica. Lavras - MG. Lavras, Cerne, v. 1, n. 1, p. 64-72, 1994.

RIBEIRO, A. I. Mecanização no preparo de solo em áreas degradadas por mineração na Floresta Nacional do Jamari (Rondônia - BR). 2005. 157 f. Tese (Doutorado em Engenharia Agrícola) - Universidade Estadual de Campinas, São Paulo.

RIBEIRO, J.F.; WALTER, B.M.T. Fitofisionomias do bioma cerrado. In: SANO, S. M.; ALMEIDA, S.P.(Eds.). Cerrado: ambiente e flora. Planaltina: EMBRAPA, 1998. p. 89-166.

SALLES, J. C. \& SCHIAVINI, I. Estrutura e composição do estrato de regeneração em um fragmento florestal urbano: implicações para a dinâmica e a conservação da comunidade arbórea. Acta Botânica Brasílica, v. 21, n. 1, p.223-233, 2007.

SIMINSKI, A., MANTOVANI , M., REIS, M. S., FANTINI, A. C. Sucessão florestal secundária no município de São Pedro de Alcântara, litoral de Santa Catarina: estrutura e diversidade. Ciência Florestal, v. 14, n. 1, p. 21-33, 2004.

SIQUEIRA, E.R. et al. Efeito do peso ao abate sobre o crescimento e caracteres da carcaça de cordeiros Santa Inês e mestiços Bergamácia $x$ Corriedale, terminados em confinamento. In: Reunião Anual Da Sociedade Brasileira De Zootecnia, 39, 2002, Recife. Anais, SBZ, 2002. 1 CD-ROM.

SOBRADE. Anais. BALENSIEFER, Maurício (Coord.). VI Seminário Brasileiro sobre Recuperação de Áreas Degradadas. Trabalho apresentado ao Congresso Latino-americano sobre recuperação de Áreas Degradadas. Curitiba, 2005. 
ANEXOS 
Ata da Reunião de Instalação do Conselho do Centro de Referência em Conservação da Natureza e Recuperação de Áreas Degradadas e eleição de sua Diretoria.

Realizou-se aos vinte e cinco dias do mês de outubro na sala de reuniões do Laboratório de Dendrologia no Departamento de Engenharia Florestal da Faculdade de Tecnologia/UnB às dezesseis horas a reunião com a seguinte pauta: 1)Informes, 2) Instalação do Conselho e Declaração do início das atividades ,3) Indicação dos membros da diretoria para apreciação da reitoria 4)Outros Assuntos. Estiveram presentes os membros-fundadores: Augusto César Franco, Carmen Regina Mendes de Araújo Correia, Christopher William Fagg, Jeanine Maria Felfili, John Du Vall Hay, José Roberto Rodrigues Pinto, Manoel Claúdio da Silva Júnior, Mercedes Maria da Cunha Bustamante, Mundayatan Haridasan, Nabil Joseph Eid e Reuber Albuquerque Brandão. Justificaram a ausência os membros fundadores: Humberto Abdalla Júnior, José Camapum de Carvalho, Laís Maria Borges de Mourão Sá, Leila Chalub , Newton Moreira de Sousa e Sérgio Koide. A professora Jeanine, coordenadora da reunião, iniciou a reunião informando a todos a aprovação, pelo Consuni, do Centro de Referência em Conservação da Natureza e Recuperação de Áreas Degradadas (CRAD), em reunião datada de 05 de outubro de 2007. Informou também que além dos recursos de capital no valor de $\mathrm{R} \$ 750.000,00$ recebidos por descentralização da CODEVASF, foram doados ao CRAD o valor de $\mathrm{R} \$ 500.000,00$ que permitirá a construção de todos os espaços previstos para o CRAD. Informou também que foi solicitado ao Ministério do Meio Ambiente o valor de $\mathrm{R} \$ 250.000,00$ como recursos de custeio para o ano de 2007 e o valor de R \$378.000,00 para o ano de 2008 também para custeio, além disto, a professora Jeanine informou que houve uma solicitação ao Ministério do Meio Ambiente que até o ano de 2011 sejam garantidos repasses para o CRAD de R\$ $300.000,00$ ao ano para custeio. A professora Jeanine relatou sobre o curso de capacitação oferecido a comunidades rurais da região de Paracatu-MG, com recursos do MMA-PNF, repassados pela FAO e que se constituiu na primeira atividade do CRAD, apresentou fotos documentando o evento e informou que está sendo preparado um curso semelhante para as comunidades rurais da região de Januária, norte do estado de Minas Gerais. A professora Mercedes informou sobre a formação da Rede de Pesquisa para o Desenvolvimento Sustentável do Cerrado que é uma iniciativa do Ministério da Ciência e Tecnologia e que a primeira ação da rede será a criação de um banco de dados e de uma página na internet e posteriormente a Rede será transformada em Programa a exemplo do que já existe para outros biomas, informou ainda que a Rede será parceira do CRAD. Às 16 horas e trinta minutos a professora Jeanine declarou iniciados os trabalhos de instalação do conselho do CRAD, conforme consta no artigo 15 do seu Regimento.Após a instalação do Conselho a professora Jeanine deu prosseguimento à reunião, fazendo a leitura do artigo 18 (corrigido) parágrafo único do Regimento onde consta como se dá a escolha da Diretoria. Em seguida, solicitou a indicação dos membros candidatos para os cargos, sendo na oportunidade indicados: professora Jeanine para Diretor Presidente, professor José Roberto para Diretor Vice-Presidente e a técnica Carmen Regina para Diretor Administrativo. Passou-se à votação em cédula conforme consta no artigo 26 (já corrigido) do Regimento. Após a votação, procedeu-se a apuração dos votos e os membros foram eleitos por unanimidade. O professor Nabil solicitou esclarecimentos sobre a possibilidade de revisões futuras no Regimento, caso houvesse necessidade, ao que a professora Jeanine informou que compete ao Conselho agora instalado proceder alterações em conformidade com o Regimento atual. Decidiu- 
se também que em conformidade com o artigo 19 o mandato da Diretoria, APÓS A NOMEAÇÃO DO MAGNÍFICO Reitor será de três anos. Decidiu-se também a eleita Diretora Administrativa elaborará um cronograma de reuniões trimestrais para o Conselho e que o submeterá à aprovação posterior dos membros. Sugeriu-se que na próxima reunião do Conselho, provavelmente em fevereiro de 2008, se defina sobre a implantação de modelos de recuperação de áreas degradadas na sub-bacia do rio Paracatu. A professora Jeanine destacou a importância das pesquisas a serem desenvolvidas pelo CRAD, dada a escassez de informações sobre as fitofisionomias do bioma Cerrado. Não havendo nada mais a tratar, eu, Carmen Regina Mendes de Araújo Correia, lavrei a presente Ata. 
ANEXO - 2. REGIMENTO INTERNO DO CRAD/UnB.

REGIMENTO INTERNO DO CENTRO DE REFERÊNCIA EM CONSERVAÇÃO DA NATUREZA E RECUPERAÇÃO DE ÁREAS DEGRADADAS

\section{Capítulo I - Da Natureza e das Finalidades}

Art. $1^{\circ}$ O Centro de Referência em Conservação da Natureza e Recuperação de Áreas Degradadas CRad é um centro de caráter multidisciplinar da Universidade de Brasília.

$\S 1^{\circ} \mathrm{O}$ CRad rege-se por este Regimento Interno e pelas disposições regulamentares aplicáveis e tem duração por prazo indeterminado.

$\S 2^{\circ}$ São objetivos do CRad:

I - promover e divulgar, cientificamente, estudos e pesquisas, bem como atividades de extensão em conservação da natureza e recuperação de áreas degradadas, visando a aprofundar os conhecimentos relativos a esse setor, bem como desenvolver modelos demonstrativos de recuperação e projetos em temas pertinentes às áreas de conhecimento referidas;

II - incentivar o aprimoramento científico de profissionais nas áreas de conservação da natureza e recuperação de áreas degradadas e subsidiá-los para atividades de extensão e educação ambiental;

III - contribuir para a pesquisa e o aperfeiçoamento do ensino, em todos os níveis, inclusive por meio da promoção de cursos de graduação e de pós-graduação, profissionalizantes, de especialização, capacitação de produtores rurais, oficinas, seminários, simpósios, conferências, congressos, mesas redondas, workshops, encontros, cursos de extensão, estágios, inclusive de pós-doutoramento, relativos à conservação da natureza e recuperação de áreas degradadas;

IV - promover o aperfeiçoamento científico de seus membros;

V - desenvolver pesquisas, consultorias, prestação de serviços, de âmbito nacional e internacional, nas áreas de sua atuação;

$\S 3^{\circ}$ Para a realização dos seus objetivos, o CR-ad poderá:

I - discutir temas sobre conservação da natureza e recuperação de áreas degradadas, em reuniões de qualquer natureza, em publicações especializadas, fóruns eletrônicos ou presenciais e por quaisquer outros meios de comunicação;

II - contribuir com os poderes legislativo, executivo e judiciário, inclusive com as agências reguladoras e demais órgãos da administração pública em geral, para o aperfeiçoamento dos conhecimentos científicos e desenvolvimento de tecnologias para a área de conservação da natureza e recuperação de áreas degradadas; 
III - propor a vinculação da Universidade de Brasília em convênios, contratos, parcerias ou quaisquer outros instrumentos que envolvam atuação conjunta, prestação de serviços, consultorias, estudos e pesquisas com entidades públicas e privadas, nacionais ou internacionais;

IV - fazer-se representar nas reuniões, assembléias e solenidades de caráter cívico, científico ou literário e também em festividades que não contrariem seus objetivos regimentais;

V - editar publicações, tais como boletins, revistas, estudos e livros;

VI - implantar e manter um Centro de Documentação;

VII - manter páginas eletrônicas pertinentes às suas áreas de atuação, agregadas ou desagregadas, dependentes ou independentes entre si.

Art. $2^{\circ} \mathrm{O}$ CR-ad não se manifestará sobre quaisquer assuntos de natureza religiosa ou político-partidária, sendo vedada qualquer participação em campanhas públicas ou eleitorais de interesse político partidário, podendo, entretanto, elaborar estudos, pesquisas, consultorias ou serviços para partidos políticos.

\section{Capítulo II - Dos Membros}

Art. $3^{\circ}$ Serão considerados membros do CRad exclusivamente as pessoas físicas que forem admitidas nesta qualidade, de acordo com as condições estabelecidas no presente Regimento Interno, os quais serão divididos nas seguintes categorias: membrosfundadores, membros-pesquisadores, membros-colaboradores e membros-honorários.

I - São membros-fundadores: as pessoas físicas que integram, no ato da constituição do CRad, o grupo proponente do projeto.

II - São membros-pesquisadores: as pessoas físicas que venham a ser admitidas como membros efetivos do CRad, de acordo com as condições estabelecidas no presente Regimento Interno.

III - São membros-colaboradores: as pessoas físicas com relevante atuação na área de conservação da natureza e recuperação de áreas degradadas de qualquer espécie, que, na forma deste Regimento Interno, demonstrem interesse em colaborar com as atividades do CRad.

IV - São membros-honorários: as personalidades que, por seu trabalho excepcional, tiveram contribuição singular para o desenvolvimento das pesquisas sobre conservação da natureza e recuperação de áreas degradadas de qualquer espécie.

Parágrafo único. Os membros-fundadores são membros-pesquisadores natos.

Art. 4 Ficará disponível na página eletrônica do CRad a lista de todos os seus membros, separados por categorias, com inscrição por ordem cronológica, prevalecendo 
o dia da efetivação da sua admissão assim como serão disponibilizadas listas com as instituições parceiras.

\section{Capítulo III - Da Admissão}

Art. $5^{\circ}$ Os membros-pesquisadores do CRad serão admitidos mediante a submissão de proposta de pesquisa assinada, a qual deverá ser aprovada pela Diretoria do CRad.

$\S 1^{\circ}$ Só será apreciada a proposta de admissão, se acompanhada de curriculum vitae completo. A Diretoria, com o propósito de decidir sobre a admissão de novo membro, poderá solicitar informações adicionais, verificar as informações já fornecidas, e/ou solicitar apresentação pública ou reservada de temática específica sobre estudo em conservação da natureza e recuperação de áreas degradadas.

$\S 2^{\circ}$ As propostas de novos membros serão submetidas à aprovação da Diretoria na reunião seguinte.

$\S 3^{\circ} \mathrm{Na}$ hipótese da Diretoria decidir pela não-aprovação da proposta de admissão, a proposta somente poderá ser renovada após o decurso de 1 (um) ano, contado da data de realização da reunião que deliberou sobre a referida proposta.

$\S 4^{\circ}$ A aprovação da proposta do novo membro será comunicada ao interessado, o qual terá seis meses para apresentar plano de trabalho pertinente à pesquisa proposta. $\mathrm{O}$ descumprimento desse prazo, se não justificado, implicará a não-admissão do proponente pesquisador, aplicando-se o disposto no parágrafo anterior.

$\S 5^{\circ}$ O Plano de trabalho apresentado tempestivamente será avaliado por membro da Diretoria especificamente designado por seus pares para tanto. Se aprovado, o proponente será admitido definitivamente como pesquisador do CRad.

$\S 6^{\circ}$ Caberá à Diretoria avaliar casos de excepcional dispensa dos procedimentos previstos neste artigo, submetendo a proposta de inclusão de membro-pesquisador para deliberação da Conselho, nos termos do art. 15, II.

Art. $6^{\circ}$ Os membros-colaboradores do CRad serão admitidos mediante indicação de um membro-pesquisador, mediante a submissão de plano de trabalho assinado, o qual deverá ser aprovado pela Diretoria do CRad.

Art. $7^{\mathbf{0}}$ Os membros-honorários serão admitidos mediante deliberação da Diretoria, por unanimidade após apreciação da proposta embasada que deverá ser encaminhada por um membro-pesquisador.

\section{Capítulo IV - Das Atribuições dos Membros}

Art. $8^{\mathbf{0}}$ São atribuiçõoes dos membros do CRad, de qualquer categoria:

I - participar das atividades promovidas pelo CRad; 
II - apresentar, nas reuniões internas do CRad, manifestações pessoais, indicações, requerimentos, moções, sugestões, propostas, comunicações e representações em conformidade com os objetivos do CRad;

III - participar de debates, integrar comissões permanentes e especiais e receber delegações;

IV - participar de projetos ou quaisquer outras atividades do CRad.

Art. $9^{\circ}$ São atribuições exclusivas dos membros-pesquisadores:

I - coordenar comissões de pesquisa permanentes ou especiais, inclusive comissão de editoração;

II - coordenar estudos, pesquisas e projetos quando designados pela Diretoria ou pelos coordenadores das comissões permanentes ou especiais;

III - propor à Diretoria a análise de matérias que visem a consecução dos objetivos do CRad.

\section{Capítulo V - Dos Deveres dos Membros}

Art. 10. São deveres dos membros do CRad, de qualquer categoria:

I - concorrer lealmente para o cumprimento dos objetivos do CRad, desempenhando as funções para as quais forem designados;

II - colaborar com as pesquisas e atividades de ensino extensão e educação ambiental em curso no CRad, mediante o compartilhamento de sua vivência profissional e acadêmica relacionada a área de conservação da natureza e recuperação de áreas degradadas;

III - observar o Regimento Interno bem como as deliberações tomadas pela Diretoria;

IV - Proceder a recadastramento trienal, cuja data limite será contada a partir da admissão ao CRad para a continuidade nos quadros do mesmo.

Art. 11. São deveres dos membros-pesquisadores:

I - integrar ao menos uma comissão permanente ou especial;

II - publicar, regularmente, em revista especializada, em livros ou na página eletrônica do CRad;

III - Desenvolver, regularmente, atividades de disseminação, extensão e educação ambiental nas áreas de conservação da natureza e recuperação de áreas degradadas.

\section{Capítulo VI - Das Sanções}


Art. 12. A Diretoria poderá aplicar aos membros-pesquisadores do CRad as seguintes sanções pela inobservância de qualquer dos deveres estabelecidos neste Regimento Interno, obedecidos os princípios da motivação, razoabilidade, contraditório e ampla defesa:

(a) advertência reservada;

(b) exclusão.

Art. 13. Qualquer dos membros do CRad poderá, ainda, ser excluído, quando não responder tempestivamente ao recadastramento trienal.

$\S 1^{\circ} \mathrm{O}$ membro que não responder ao recadastramento será notificado de sua possível exclusão e instado a se manifestar.

$\S 2^{\circ}$ Decorrido o prazo de um mês sem que haja manifestação, a exclusão ocorrerá automaticamente, dando-se baixa do nome do ex-membro no cadastro próprio do CRad.

$\S 3^{\circ}$ A manifestação intempestiva, efetuada após a exclusão, será considerada como uma nova proposta de admissão.

\section{Capítulo VII - Dos Órgãos do CRad}

Art. 14. Integram o Crad:

I. Conselho;

II. Diretoria.

\section{Capítulo VIII - Do Conselho}

Art. 15. O Conselho será composto pelos membros-pesquisadores do CRad.

Parágrafo único. O primeiro Conselho do CRad será instalado pelos membrosfundadores, competindo-lhes declarar, solenemente, o início das atividades do Centro.

Art. 15. O Conselho instalar-se-á em primeira convocação com a presença da maioria simples de seus membros-pesquisadores e, em segunda convocação, com qualquer número, reunindo-se:

I - ordinariamente, com periodicidade trimestral;

II - Até o final dos 3 (Três) primeiros meses de cada ano, para deliberar sobre o relatório das atividades da Diretoria e a prestação de contas, relativa ao ano civil findo, o planejamento do exercício seguinte, bem como indicar, a cada 3 (três) anos, os membros da Diretoria do CRad para apreciação da Reitoria da UnB; 
III - extraordinariamente, sempre que convocado pela Diretoria, ou por requerimento subscrito, no mínimo, por 2/5 (dois quintos) dos membros-pesquisadores do CRad.

$\S 1^{\circ}$ A convocação far-se-á por aviso na página eletrônica do CRad, com no mínimo 8 (oito) dias de antecedência da data prevista para a realização da respectiva reunião do Conselho, ou por intermédio de e-mail, e deverá conter, além da data, local e hora da reunião, bem como sua pauta.

$\S 2^{\circ}$ Cada um dos membros-pesquisadores participantes do Conselho terá direito a um voto nas deliberações plenárias. Os membros-honorários e os membros-colaboradores poderão participar do Conselho com direito a voz.

$\S 3^{\circ}$ Os membros-pesquisadores deverão se abster de votar as deliberações que puderem beneficiá-los de modo particular ou em que tiverem interesse conflitante com o do CRad.

$\S 4^{\circ}$ As deliberações do Conselho serão tomadas por maioria simples de votos dos membros-pesquisadores a ela presentes, respeitado o quorum de metade mais um dos membros-pesquisadores do CRad em primeira convocação, ou com menos de 1/3 (um terço) nas convocações seguintes.

Art. 16. Compete privativamente ao Conselho:

I - aprovar o relatório das atividades da Diretoria referentes ao ano civil findo, bem como o planejamento do exercício seguinte;

II - indicar e propor a substituição, antes do término do mandato de 3 (três) anos, dos membros da Diretoria, sendo que, para a destituição de qualquer desses membros será necessário o voto favorável de no mínimo $2 / 3$ (dois terços) dos membros-pesquisadores presentes à reunião do Conselho, especialmente convocada para esse fim, não podendo ela deliberar em primeira convocação sem a maioria absoluta dos membrospesquisadores do CRad ou com menos de 1/3 nas convocações seguintes;

III - propor a alteração do Regimento Interno do CRad por, no mínimo, 2/3 (dois terços) de seus membros-pesquisadores;

IV - propor a extinção do CRad pelo voto favorável de, no mínimo, 2/3 (dois terços) de seus membros-pesquisadores.

\section{Capítulo VIII - Da Diretoria}

Art. 17. A Diretoria é o órgão responsável pela gestão operacional e administrativa do CRad.

Art. 18. A Diretoria será composta por 1 (um) Diretor(a) Presidente, 1 (um) Diretor Vice-Presidente e 1 (um) Diretor-Administrativo, os quais se obrigam a cumprir e fazer cumprir este Regimento Interno e as deliberações do Conselho em direção ao escopo maior dos fins universitários. 
$\S 1^{\text {o }}$ A Diretoria será nomeada pelo Reitor da Universidade de Brasília, mediante indicação do Conselho do CRad para o período de 3 (três) anos, permitida a recondução.

$\S 2^{\circ}$ Os membros da Diretoria substituir-se-ão nas respectivas faltas e impedimentos, pela ordem em que se acham referidos no caput deste Artigo.

$\S 3^{\circ}$ Perderá o cargo o Diretor que, injustificadamente, faltar a mais de 4 (quatro) reuniões de Diretoria, em um mesmo ano.

$\S 5^{\circ}$ Ocorrendo vagas em virtude de renúncia ou impedimento permanente de quaisquer dos membros da Diretoria, caberá aos membros do Conselho, no prazo máximo de 30 (trinta) dias, em reunião ordinária ou extraordinária, indicar nomes dentre os membrospesquisadores para a apreciação da Reitoria.

Art. 19. São atribuições da Diretoria do CRad, além de outras previstas neste Regimento Interno, as seguintes:

I - promover as atividades destinadas a cumprir os objetivos do CRad;

II - elaborar o planejamento anual e encaminhá-lo à Conselho do CRad;

III - criar e implementar as Comissões Permanentes e Especiais;

IV - propor convênios, intercâmbios, parcerias, contratos, dentre outros vínculos entre a Universidade de Brasília e entidades públicas ou privadas, nacionais e internacionais;

V - representar o CRad em convênios, intercâmbios, parcerias, contratos, dentre outros vínculos entre a Universidade de Brasília e entidades públicas ou privadas, nacionais e internacionais;

VI - elaborar o relatório de suas atividades e balanço anual do CRad, relativos aos anos fiscais findos e encaminhá-los ao Conselho ;

VII - promover a realização de seminários, cursos, eventos, atividades e serviços visando a consecução dos objetivos do CRad;

VIII - elaborar propostas de alteração do Regimento Interno e submetê-las à apreciação do Conselho.

$\S 1^{\circ}$ Os compromissos do CRad serão firmados por intermédio do seu Diretor Presidente.

$\S 2^{\circ} \mathrm{O}$ patrimônio sob responsabilidade do CRad será administrado pela Diretoria ou por delegação expressa a um dos membros-pesquisadores do CRad.

$\S 3^{\circ}$ A Diretoria deliberará sempre por maioria de votos dos membros presentes à respectiva reunião, sendo de 2 (dois) membros o quorum mínimo.

Art.20. São atribuições do Diretor Presidente do CRad:

I - zelar pela fiel execução do Regimento Interno e das deliberações do Conselho ;

II - coordenar e presidir as reuniões da Diretoria; 
III - assinar, junto com o Diretor-Vice-Presidente ou com o Diretor Administrativo, contratos de qualquer natureza, convênios, termos de parceria ou outros instrumentos derivados da atuação do CRad;

IV - organizar a pauta de cada reunião da Diretoria;

$\mathrm{V}$ - indicar os coordenadores e integrantes de Comissões Permanentes ou Especiais, submetendo-a à ratificação da Diretoria;

VI - acompanhar os debates e trabalhos das Comissões Permanentes ou Especiais;

VII - incluir na pauta das reuniões da Diretoria questões relevantes apresentadas por requerimento de membros-pesquisadores do CRad;

VIII - administrar os recursos do CRad ou delegar sua administração ao Diretor de Administrativo;

IX - representar o CRad em eventos no país e no exterior, podendo delegar tal representação, em cada caso, a 1 (um) membro-pesquisador a seu critério.

Art. 21. Ao Vice-Presidente cumpre substituir o Presidente em suas ausências ou impedimentos, bem como auxiliá-lo em todas as suas tarefas administrativas.

Art. 22. Caberá ainda ao Diretor Vice-Presidente:

I - IV - Supervisionar as atividades do CRad;

II - Sistematizar as informações das atividades do CRad;

III - Providenciar acesso às informações geradas nos projetos do CRad.

Art. 23. São Atribuições do Diretor-Administrativo do CRad:

I - Substituir o Diretor-Presidente e o Diretor Vice-Presidente, nas suas ausências ou impedimentos;

II - Auxiliar o Diretor-Presidente e o Diretor Vice-Presidente na administração e organização das atividades de ensino, pesquisa, extensão e educação ambiental do CRad;

III - A guarda e administração dos bens patrimoniais;

IV - O pagamento das despesas ordenadas pelo Diretor Presidente;

V - A apresentação das contas do exercício findo;

VI - Compatibilizar as atividades do CRad;

VI - A elaboração da proposta de orçamento para o exercício seguinte a ser apresentada pela Diretoria ao Conselho.

$\S 1^{\circ} \mathrm{O}$ Diretor-Administrativo poderá ser docente ou funcionário(a) de nível superior ligado às atividades do Centro, devendo ser membro-pesquisador do CRad.

\section{Capítulo IX - Das Comissões Permanentes e Especiais}


Art. 24. As atividades de desenvolvimento e aprimoramento técnico-científico do CRad serão executadas por intermédio de Comissões Permanentes ou Especiais, às quais competirá promover pesquisas e estudos no setor de conservação da natureza e recuperação de áreas degradadas.

$\S 1^{\circ}$ As Comissões Permanentes serão criadas pela Diretoria.

$\S 2^{\circ}$ A Diretoria poderá instituir Comissões Especiais fixando-lhe os objetivos, a duração e a composição.

$\S 3^{\circ}$ Cada Comissão Permanente e Especial será integrada por membros-pesquisadores e coordenada por um membro-pesquisador escolhido pelo Diretor-Presidente do CRad.

$\S 4^{\circ}$ Os membros das Comissões que faltarem, sem causa justificada, a 3 (três) reuniões consecutivas, salvo licença concedida pelo Diretor-Presidente do CRad, serão automaticamente excluídos da respectiva Comissão e poderão sofrer a sanção descrita no art. 12 (b). A falta justificada será apresentada pelo membro à respectiva Comissão.

$\S 5^{\circ}$ Os coordenadores das Comissões Permanentes ou Especiais ficam obrigados a enviar ao Presidente do CRad os relatórios finais, nos prazos pré-estabelecidos, sob pena de destituição, bem como a informá-lo de todos os fatos que dificultem ou perturbem o andamento dos trabalhos.

$\S 6^{\circ}$ Os estudos e trabalhos desenvolvidos pelas Comissões poderão ter o auxílio de membros-colaboradores ou de membros-honorários.

\section{Capítulo XI - Das Eleições}

Art. 25. Até o final dos 3 (três) primeiros meses do ano, a cada três anos, o Conselho procederá à realização da eleição dos membros da Diretoria, para o triênio seguinte, a serem indicados para apreciação da Reitoria.

$\S 1^{\circ}$ Só poderão votar e ser votados os membros-pesquisadores do CRad que se acharem em dia com suas obrigações de pesquisa perante ao menos uma das Comissões Permanentes ou Especiais assim declarados em ata de reunião da respectiva Comissão. O Diretor Presidente fará divulgar, com antecedência mínima de 60 (sessenta) dias da data da eleição, a relação dos membros aptos a votarem e serem votados.

$\S 2^{\circ}$ Somente poderão ser votados os membros-pesquisadores cujos nomes tenham sido registrados perante a Diretoria, até 40 (quarenta) dias antes da data designada para as eleições. O registro poderá ser requerido pelo próprio candidato ou por seu procurador. Após o registro, somente será admitida a substituição de nomes registrados em caso de falecimento, renúncia à candidatura ou impedimento decorrente de abertura de procedimento administrativo disciplinar.

$\S 3^{\circ} \mathrm{O}$ voto será exercido mediante cédula impressa ou por meio eletrônico, da qual constarão os nomes de todos os candidatos. 
$\S 4^{\circ}$ Só serão computados os votos exercidos na forma a que se refere o parágrafo anterior quando recebidos pelo Presidente do CRad até o momento do encerramento da votação.

$\S 5^{\circ}$ Encerrada a votação será iniciada, imediatamente, a apuração dos votos, que não será interrompida até a declaração do resultado.

$\S 6^{\circ}$ Considerar-se-á eleito, em caso de empate, o membro mais antigo. Persistindo o empate será considerado eleito o mais idoso.

\section{Capítulo XII - Das Publicações e do Conselho Editorial}

Art. 26. O Conselho Editorial do CRad é composto por 3 (três) Conselheiros, indicados e nomeados pela Diretoria.

$\S 1^{\circ}$ Caberá ao Conselho Editorial propor à diretoria o sistema de publicações, ajudar na sua implementação, selecionar os materiais para inclusão em toda e qualquer publicação editada, patrocinada ou, de qualquer forma chancelada pelo CRad.

$\S 2^{\circ}$ É facultado a todos os membros do CRad enviarem trabalhos e pesquisas para publicação, os quais serão analisados e selecionados pelo Conselho Editorial.

$\S 3^{\circ} \mathrm{O}$ Conselho Editorial poderá aprovar a publicação de estudos, pesquisas ou artigos de alguém que não seja membro do CRad desde que atenda aos seus objetivos e seja elaborado por profissional de reconhecido conhecimento científico no setor de conservação da natureza e recuperação de áreas degradadas.

\section{Capítulo XIII - Dos créditos}

Todas os produtos de pesquisa, extensão, educação ambiental e demais atividades relacionadas a projetos desenvolvidos no CRad ou em parceria ou pela utilização de equipamentos ou base de dados do CR-ad devem explicitamente dar créditos ao mesmo, por meio de agradecimentos, colocação do logotipo ou outro meio adequado.

\section{Capítulo XIV - Das Disposições Gerais}

Art. 27. A proposta de alteração deste Regimento Interno obedecerá ao seguinte procedimento:

(a) formalização de proposta pela Diretoria ou mediante subscrição de, no mínimo, 1/5 dos membros-pesquisadores;

(b) divulgação da proposta para todos os membros com, pelo menos, 30 (trinta) dias de antecedência da data da reunião do Conselho especialmente convocada para deliberar sobre a alteração regimental; 
(c) o quorum para aprovação será de $2 / 3$ (dois terços) dos membros presentes ao Conselho, não podendo ela deliberar, em primeira convocação, sem a maioria absoluta dos membros-pesquisadores do CRad, ou com menos de $1 / 3$ (um terço) nas convocações seguintes.

Art. 28. A proposta de extinção do CRad depende de manifestação de mais de $2 / 3$ (dois terços) de seus membros-pesquisadores, manifestada por escrito, por duas vezes, com intervalo de 30 (trinta) dias entre uma e outra manifestação, e o patrimônio a ele alocado deverá ser transferido em partes iguais às Unidades da Universidade de Brasília cujas temáticas vêm representadas no Conselho do Crad. 
ANEXO - 3. NOME VULGAR E CIENTÍFICO DAS ESPÉCIES UTILIZADAS NOS PLANTIOS DE RECUPERAÇÃO DE ÁREAS DEGRADADAS REALIZADOS PELO CRAD/UnB, NA BACIA DO SÃO FRANCISCO, PARACATU - MG.

\begin{tabular}{|c|c|}
\hline Nome Vulgar & Nome científico \\
\hline Açoita cavalo & Luehea paniculata Mart. \& Zucc. \\
\hline Amburana & Amburana cearensis (Allemao) A.C.Smith \\
\hline Amora & Morus nigra $\mathrm{L}$. \\
\hline Angico branco & Anadenanthera falcata Speg. \\
\hline Angico monjolo & Acacia polyphylla DC. \\
\hline Angico vermelho & Anadenanthera colubrina (Vell.) Brenan \\
\hline Araça do cerrado & Psydium cattleianum Sabine \\
\hline Araribá & Centrolobium robustum \\
\hline Araticum & Annona crassiflora \\
\hline Aroeira & Myracrodruon urundeuva Allemao \\
\hline Aroeirinha & Schinus terebinthifolia Raddi \\
\hline Barbatimão & Stryphnodendron adstringens (Mart.) Coville \\
\hline Baru & Dipteryx alata Vogel \\
\hline Bolsa de pastor & Zeyheria digitalis \\
\hline Cabo de machado & Pouteria torta (Mart.) Ra DTK \\
\hline Cagaita & Eugenia dysenterica Mart. ex DC. \\
\hline Caixeta & Schefflera morototonii (Aubl.) Maguire, Steyerm. \& Frodin \\
\hline Camboata & Cupania oblongifolia \\
\hline Capa rosa & Neea theifera Orsted \\
\hline Canela & Aspidosperma discolor DC. \\
\hline Canjerana & Cabraela canjerana (Vell.) Mart. \\
\hline Caqui do cerrado & Diospyros hispida DC. \\
\hline Caju & Anacardium occidentale L. \\
\hline Capitão & Terminalia argêntea Mart. et Zucc. \\
\hline Capituva & Metrodorea stipularis Mart. \\
\hline Caroba & Jacaranda cuspidifolia Mart. ex A.DC. \\
\hline Carvoeiro & Sclerolobium paniculatum Vogel \\
\hline Cedro & Cedrela fissilis Vell. \\
\hline Cereja & Cerasus auvim (L.) Moench \\
\hline Cereja de pobre & Cerasus vulgaris \\
\hline Chicha & Sterculia striata A.St.-Hil. \& Naudin \\
\hline Coco jerivá & Arecastrum romanzoffianum (Cham.) Glassm. \\
\hline Cotieira & Joannesia princeps Vell. \\
\hline
\end{tabular}




\begin{tabular}{|c|c|}
\hline Crindiuva & Trema micrantha \\
\hline Curriola & Pouteria ramiflora (Mart.) \\
\hline Embaúba & Cecropia pachystachya Trécul \\
\hline Farinha seca & Albizia hassleri \\
\hline Faveira & Peltophorum dubium (Spreng.) Taub. \\
\hline Favela & Dimorphandra mollis Benth \\
\hline Gabiroba & Campomanesia eugenioides (Cambess) D. Legrand \\
\hline Garapa & Apuleia leiocarpa (Vogel) J.F.Macbr. \\
\hline Gonçalo alves & Astronium fraxinifolium Schott ex Spreng. \\
\hline Grão de galo & Pouteria sp. \\
\hline Imbiruçu & Pseudobombax tomentosum \\
\hline Ingá & Inga laurina $(\mathrm{Sw}$.$) Willd.$ \\
\hline Ipê amarelo & Tabebuia ochracea (Cham.) Standley \\
\hline Ipê branco & Tabebuia sp. \\
\hline Ipê caraiba & Tabebuia aurea (Manso) Benth. \& Hook.f. ex S.Moore \\
\hline Ipê rosa & Tabebuia heptaphylla (Vell.) Toledo \\
\hline Ipê roxo & Tabebuia impetiginosa (Mart. ex A.DC.) Standley \\
\hline Ipê verde & Cybistax antisyphilitica (Mart.) Mart. ex DC. \\
\hline Jacarandá bico de pato & Machaerium aculeatum Raddi \\
\hline Jacarandá do cerrado & Dalbergia miscolobium Benth. \\
\hline Jamelão & Syzygium sp. \\
\hline Jatobá do cerrado & Hymenaea stigonocarpa Mart. ex Hayne \\
\hline Jatobá da mata & Hymenaea courbaril L. \\
\hline Jenipapo & Genipa americana $\mathrm{L}$. \\
\hline Louro & Cryptocarya aschersoniana $\mathrm{Mez}$ \\
\hline Mama cadela & Brosimum gaudichaudii Trécul \\
\hline Mangaba & Hancornia speciosa \\
\hline Maria pobre & Dilodendron bipinnatum Radlk. \\
\hline Marmelada & Alibertia edulis \\
\hline Marmelinho & Licania humilis Cham. Ex Schlecht \\
\hline Mata cachorro & Simarouba versicolor A.St.-Hil. \\
\hline Murici macho & Byrsonima verbasifolia \\
\hline Mutamba & Guazuma ulmifolia Lam. \\
\hline Olho de boi & Diospero burchellii. \\
\hline Paineira cerrado & Pseudobombax sp. \\
\hline Pau de óleo & Copaifera langsdorffii Desf. \\
\hline Pau ferro & Caesalpinia ferrea Mart \\
\hline Pau ferro liso & Machaerium scleroxylon Tul. \\
\hline
\end{tabular}




\begin{tabular}{|l|l|}
\hline Pau formiga & Triplaris gardneriana Weddell \\
\hline Pau mangue & Guarea guidonia \\
\hline Pau pereira & Platycyamus regnelii \\
\hline Pau santo & Kielmeyera coriacea Mart. \& Zucc. \\
\hline Pau terra & Qualea grandiflora \\
\hline Pequi & Caryocar brasiliense Cambess. \\
\hline Pente de macaco & Apeiba tibourbou Aubl. \\
\hline Peroba & Aspidosperma polyneuron M. Arg. \\
\hline Pimenta de macaco & Xylopia aromatica \\
\hline Pombo & Tapirira guianensis \\
\hline Sambaiba & Curatella americana L. \\
\hline Sobre & Emmotum nitens (Benth.) Miers \\
\hline Sucupira branca & Pterodon pubescens (Benth.) Benth. \\
\hline Sucupira preta & Bowdichia virgilioides Kunth \\
\hline Tamboril & Enterolobium contorsiliquum (Vell.) Morong \\
\hline Tingui & Magonia pubescens A.St.-Hil. \\
\hline Ucuiuba pinha do brejo & Virola sebifera \\
\hline Uvaia & Platypodium elegans \\
\hline Vinhático & Plathymenia reticulata Benth. \\
\hline
\end{tabular}


ANEXO - 4. RESOLUÇÃO DO CONSELHO UNIVERSITÁRIO No 32/2007.

\section{UNIVERSIDADE DE BRASÍLIA}

RESOLUÇÃO DO CONSELHO UNIVERSITÁRIO N. 32 /2007

RESOLVE:

Criar o Centro de Referência em Conservação da Natureza e Recuperaçāo de Áreas Degradadas, vinculado ao Gabinete do Reitor.

Brasília, 10 de outubro de 2007.

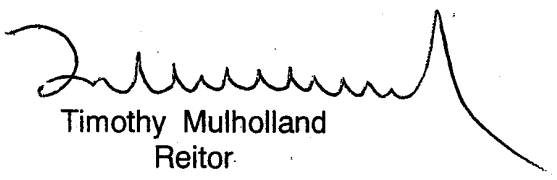

C/cópia: GRE/VRT/ACS/SCA/SOC/FT/EFL APM/André́: 